Economics Development Analysis Journal 6(3)(2017) Economics Development Analysis Journal

\title{
Analisis Penerima Raskin (Beras untuk Rumah Tangga Miskin) di Provinsi Jawa Tengah
}

\section{Siti Khomsatun ${ }^{\bowtie}$}

Badan Pusat Statistik Kabupaten Semarang, Semarang

\begin{tabular}{l} 
Info Artikel \\
\hline Sejarah Artikel: \\
Diterima April 2017 \\
Disetujui Juni 2017 \\
Dipublikasikan Agustus \\
2017
\end{tabular}

Keywords: Poor, Raskin, Central Java, Crosstabs, Different Test

\begin{abstract}
Abstrak
Pelaksanaan program raskin di lapangan menunjukkan bahwa pendistribusian raskin masih belum sesuai ketentuan. Menurut data BPS disebutkan bahwa pada tahun 2014 rata-rata jumlah raskin yang diterima oleh 20 persen rumah tangga dengan pengeluaran terendah di Jawa Tengah adalah sebanyak 5,60 kg padahal mereka seharusnya menerima $15 \mathrm{~kg}$ per bulan dan rata-rata harga yang dibayar untuk membeli raskin sebesar Rp. 2.070 per kg padahal mereka seharusnya membayar dengan harga Rp. 1.600 per kg. Sumber data yang digunakan dalam penelitian ini adalah data sekunder yang berasal dari data Susenas 2015 pada BPS Provinsi Jawa Tengah yang berisi data tentang sosial dan ekonomi rumah tangga. Teknis analisis yang digunakan adalah analisis tabulasi silang (crosstab).Hasil dari penelitian ini adalah masih ada rumah tangga yang menurut kategori kemiskinan seharusnya menerima raskin namun tidak menerima raskin dan sebaliknya terdapat rumah tangga yang tidak miskin dan seharusnya tidak menerima raskin namun menerima raskin. Rumah tangga penerima raskin yang masuk kategori sangat miskin, miskin, hampir miskin, dan rentan miskin lainnya dan menerima raskin sebanyak $15 \mathrm{~kg}$ hanya sebagian kecil, padahal seharusnya rumah tangga sasaran program raskin menerima raskin sebanyak $15 \mathrm{~kg}$ per bulan sesuai pedoman raskin. Penelitian ini memiliki tujuan menganalisis karakteristik penerima raskin di Provinsi Jawa Tengah.
\end{abstract}

\begin{abstract}
Raskin program implementation in the field shows that the distribution of raskin still not according to regulations. The agency noted that in 2014 the average number of raskin received by 20 percent of households with the lowest expenditure in Central Java is as much as $5.60 \mathrm{~kg}$ when they are supposed to receive $15 \mathrm{~kg} \mathrm{per}$ month and the average price paid to purchase raskin Rp. 2,070 per $\mathrm{kg}$ when they should be paying the price of $R p .1,600 \mathrm{per} k g$. The data used in this research is secondary data derived from the data Susenas 2015 at Statistics of Central Java Province which contains data on the social and economic households. Technical analysis is the analysis of cross tabulation (crosstab). The results of this study are still households by poverty category should receive raskin but did not receive raskin and instead there are households that are not poor and should not receive raskin but received raskin. Raskin recipient households were categorized as very poor, poor, near poor, and vulnerable other poor receive raskin as much as $15 \mathrm{~kg}$ only a small part, when it should raskin program target households receive raskin as much as $15 \mathrm{~kg}$ per month as per the guidelines raskin. This study has purpose of analysis the characteristics of raskin recipient in Centran Java.
\end{abstract}

(C) 2017 Universitas Negeri Semarang

\footnotetext{
बAlamat korespondensi:

Gedung Badan Pusat Statistik Kabupaten Semarang

Jalan Tanjung Mas Semarang Utara, Semarang, 50177

E-mail: sitikhomsatun@rocketmail.com
} ISSN 2252-6765 


\section{PENDAHULUAN}

Kemiskinan adalah kondisi di mana seseorang atau sekelompok orang tidak mampu memenuhi hak-hak dasarnya untuk mempertahankan dan mengembangkan kehidupan yang bermartabat (Bappenas dalam BPS, 2009). Hak-hak dasar antara lain : terpenuhinya kebutuhan pangan, kesehatan, pendidikan, pekerjaan, perumahan, air bersih, pertanahan, sumberdaya alam dan lingkungan hidup, rasa aman dari perlakuan atau ancaman tindak kekerasan, hak untuk berpartisipasi dalam kehidupan sosial politik.

Berdasarkan data Badan Pusat Statistik (BPS), pada tahun 2005 persentase penduduk miskin Indonesia sebesar 15,97 persen. Sejalan dengan upaya penanggulangan kemiskinan yang telah dilaksanakan oleh pemerintah dan masyarakat, persentase penduduk miskin terus mengalami penurunan meskipun melambat. Pada tahun 2016 persentase penduduk miskin Indonesia menurut BPS sebesar 10,86 persen. Adapun Persentase Penduduk Miskin di Indonesia, 2005-2016, dapat dilihat pada gambar 1.

Provinsi Jawa Tengah sebagai salah satu provinsi di Pulau Jawa masih mempunyai jumlah penduduk miskin yang relatif besar. Tabel 1 menunjukkan jumlah dan persentase penduduk miskin provinsi di Pulau Jawa. Jumlah penduduk miskin Provinsi Jawa Tengah pada tahun 2014 merupakan terbesar di Pulau Jawa. Namun demikian pada tahun 2015 dan 2016, jumlah penduduk miskin di Provinsi Jawa'Tengah menjadi terbesar kedua setelah Provinsi Jawa Timur. Sedangkan jika dilihat dari persentase penduduk miskinnya, Provinsi Jawa Tengah berada di urutan kedua setelah Provinsi DI Yogyakarta. Persentase penduduk miskin Provinsi Jawa Tengah juga masih berada di atas persentase penduduk miskin secara keseluruhan di Indonesia. Hal ini tentu harus menjadi perhatian pemerintah baik pusat maupun Pemerintah Daerah Provinsi Jawa Tengah untuk menanggulanginya. Adapun Jumlah dan Persentase Penduduk Miskin di Pulau Jawa, 2014-2016, dapat dilihat pada tabel 1.
Adapun Jumlah dan Persentase Penduduk Miskin di Provinsi Jawa Tengah, 2014-2016, dapat dilihat pada tabel 2. Berdasarkan tabel 2 diketahui bahwa jumlah penduduk miskin di wilayah pedesaan Provinsi Jawa Tengah lebih banyak jika dibandingkan dengan wilayah perkotaan Provinsi Jawa Tengah. Demikian juga untuk presentasi penduduk miskin di wilayah pedesaan Provinsi Jawa Tengah jika dibandingkan wilayah potaan Jawa Tengah.

Menurut Dumairy (1996), tingkat kesejahteraan penduduk dapat dilihat melalui alokasi pengeluaran konsumsinya. Semakin sejahtera penduduk suatu negeri semakin kecil pengeluaran konsumsinya untuk pembelian bahan pangan. Pengeluaran konsumsi penduduk yang sejahtera tidak lagi untuk keperluan pangan. Pemanfaatan institusi lokal yang tumbuh dan berkembang dalam kehidupan masyarakat pedesaan telah membantu banyak rumah tangga miskin untuk dapat bertahan hidup (Cahaya, 2015)

Pengeluaran konsumsi oleh penduduk di Provinsi Jawa Tengah masih didominasi untuk makanan, hal ini ditunjukkan dengan persentase pengeluaran per kapita untuk makanan bernilai lebih dari 50\% dari total pengeluaran per kapita. Persentase pengeluaran per kapita untuk makanan oleh penduduk miskin relatif lebih tinggi jika dibandingkan dengan penduduk tidak miskin, hal ini wajar karena dengan rendahnya pendapatan yang dimiliki oleh penduduk miskin, mereka akan mengutamakan kebutuhan yang pokok terlebih dahulu yaitu makanan.

Beras merupakan komoditas bahan makanan pokok penduduk di Provinsi Jawa Tengah. Hal ini ditunjukkan oleh 96 persen penduduk di Provinsi Jawa Tengah mengkonsumsi beras. Persentase penduduk Jawa Tengah yang mengkonsumsi beras antara di daerah pedesaan dan perkotaan lebih besar di daerah pedesaan, yaitu sebanyak 97,20 persen penduduk pedesaan Jawa Tengah mengkonsumsi beras, sedangkan penduduk perkotaan Jawa Tengah yang mengkonsumsi beras sebanyak 94,53 persen (BPS, data Survei Sosial Ekonomi Nasional 2013 diolah). 
Gambar 1. Persentase Penduduk Miskin di Indonesia, 2005-2016

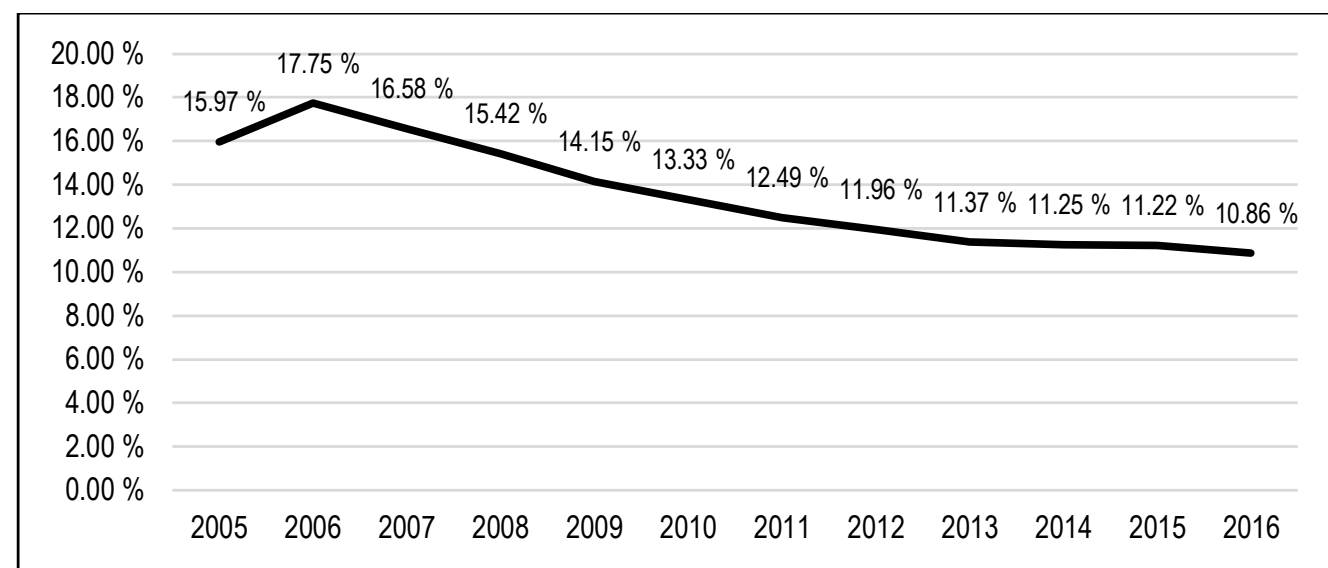

Sumber : BPS, https://www.bps.go.id, 2016

Tabel 1. Jumlah dan Persentase Penduduk Miskin di Pulau Jawa, 2014-2016

\begin{tabular}{lllllll}
\hline \multirow{2}{*}{ Wilayah } & \multicolumn{2}{l}{$\begin{array}{l}\text { Jumlah Penduduk Miskin } \\
\text { (Ribu Jiwa) }\end{array}$} & \multicolumn{5}{l}{$\begin{array}{l}\text { Persentase Penduduk Miskin } \\
(\%)\end{array}$} \\
& 2014 & 2015 & 2016 & 2014 & 2015 & 2016 \\
\hline DKI Jakarta & 393,98 & 398,92 & 384,30 & 3,92 & 3,93 & 3,75 \\
Jawa Barat & $4.327,07$ & $4.435,70$ & $4.224,32$ & 9,44 & 9,53 & 8,95 \\
Banten & 622,84 & 702,40 & 658,11 & 5,35 & 5,90 & 5,42 \\
Jawa Tengah & $4.836,45$ & $4.577,04$ & $4.506,89$ & 14,46 & 13,58 & 13,27 \\
DI Yogyakarta & 544,87 & 550,23 & 494,94 & 15,00 & 14,91 & 13,34 \\
Jawa Timur & $4.786,79$ & $4.789,12$ & $4.703,30$ & 12,42 & 12,34 & 12,05 \\
Indonesia & $28.280,01$ & $28.592,79$ & $28.005,41$ & 11,25 & 11,22 & 10,86 \\
\hline
\end{tabular}

Sumber : BPS, https://www.bps.go.id, 2016

Tabel 2. Jumlah dan Persentase Penduduk Miskin di Provinsi Jawa Tengah, 2014-2016

\begin{tabular}{|c|c|c|c|c|c|c|}
\hline \multirow[t]{2}{*}{ Wilayah } & \multicolumn{3}{|c|}{$\begin{array}{l}\text { Jumlah Penduduk Miskin } \\
\text { (Ribu Jiwa) }\end{array}$} & \multicolumn{3}{|c|}{$\begin{array}{l}\text { Persentase Penduduk Miskin } \\
(\%)\end{array}$} \\
\hline & 2014 & 2015 & 2016 & 2014 & 2015 & 2016 \\
\hline Perkotaan & $1.945,29$ & $1.837,19$ & $1.824,08$ & 12,68 & 11,85 & 11,44 \\
\hline Pedesaan & $2.891,17$ & $2.739,85$ & $2.682,81$ & 15,96 & 15,05 & 14,89 \\
\hline $\begin{array}{l}\text { Perkotaan dan } \\
\text { Pedesaan }\end{array}$ & $4.836,45$ & $4.577,04$ & $4.506,89$ & 14,46 & 13,58 & 13,27 \\
\hline
\end{tabular}

Sumber : BPS, https://www.bps.go.id, 2016 
Tabel 3. Persentase Pengeluaran Per Kapita untuk Makanan di Provinsi Jawa Tengah, 2011-2014

\begin{tabular}{cccc}
\hline \multirow{2}{*}{ Tahun } & \multicolumn{2}{c}{ Persentase Pengeluaran Per Kapita untuk Makanan } \\
Miskin & Penduduk & $\begin{array}{c}\text { Penduduk } \\
\text { Tidak Miskin }\end{array}$ & $\begin{array}{c}\text { Miskin dan Tidak } \\
\text { Miskin }\end{array}$ \\
\hline 2011 & 65,02 & 56,73 & 58,07 \\
2012 & 64,10 & 57,00 & 58,07 \\
2013 & 64,45 & 57,33 & 58,35 \\
2014 & 63,89 & 57,16 & 58,08 \\
\hline
\end{tabular}

Sumber : BPS, Data dan Informasi Kemiskinan Kabupaten/Kota, 2012-2015

Berbagai upaya penanggulangan

kemiskinan telah dilakukan oleh pemerintah bersama masyarakat melalui tiga kluster, yakni: program perlindungan sosial berbasis keluarga, di mana program raskin termasuk di dalamnya, program pemberdayaan masyarakat, dan pemberdayaan Usaha Mikro dan Kecil (UMK) dengan program Kredit Usaha Rakyat (KUR) (Sektretaris Kementerian Koordinator Bidang Kesejahteraan Rakyat dana Pedoman Umum Raskin, 2010).

Sejak krisis pangan pada tahun 1998, Pemerintah Indonesia konsisten memberikan perhatian terhadap pemenuhan hak atas pangan masyarakat yang diimplementasikan melalui Operasi Pasar Khusus (OPK). OPK memberikan subsidi beras secara targetted kepada rumah tangga miskin dan rawan pangan. Pada tahun 2002 nama OPK diubah menjadi Program Beras untuk Keluarga Miskin (Program Raskin) yang bertujuan untuk lebih mempertajam sasaran penerima manfaat. Pada tahun 2008 program ini berubah menjadi Program Subsidi Beras Bagi Masyarakat Berpendapatan Rendah, namun masih tetap disebut Program Raskin (Kementrian Koordinator Bidang Kesejahteraan Rakyat RI, 2013).

Raskin sebagai program bantuan beras bersubsidi bagi masyarakat berpendapatan rendah, merupakan bagian tak terpisahkan dari program ketahanan pangan. Program ini sebagai upaya meningkatkan akses dalam memenuhi hak dasar masyarakat miskin terhadap kebutuhan pangan. Kelompok masyarakat miskin memiliki kemampuan paling lemah dalam mengakses kebutuhan pangan, sekalipun produksi beras nasional surplus. Pemerintah memberikan bantuan subsidi beras melalui program raskin tidak hanya terhadap masyarakat yang sangat miskin dan miskin, akan tetapi juga masyarakat yang hampir miskin (Sektretaris Kementerian Koordinator Bidang Kesejahteraan Rakyat dana Pedoman Umum Raskin, 2010).

Sulton Mawardi, dkk (2007) dalam Efektivitas Pelaksanaan Raskin melakukan tinjauan dokumen dan analisis data sekunder (meta evaluasi), mengemukakan bahwa pada banyak kasus, musyawarah desa (mudes) dalam rangka menentukan rumah tangga penerima raskin, pada akhirnya menghasilkan keputusan raskin dibagi rata kepada jumlah rumah tangga yang lebih banyak atau kepada seluruh rumah tangga. Berbagai alasan yang melatarbelakangi keputusan tersebut antara lain untuk menghindari konflik, kurangnya pagu dibanding rumah tangga miskin, menghindari kecemburuan sosial, adanya tuntutan dari mereka yang tidak berhak, dan untuk mencapai target waktu penjualan beras serta pembayarannya. Penyediaan layanan ini di daerah pinggiran kota berkembang pesat tidak dapat dicapai kecuali kompleksitas sosial yang diorganisir dieksplorasi dan didiagnosis dengan benar (Walker, 2015).

Pelaksanaan program raskin di lapangan menunjukkan bahwa pendistribusian raskin masih belum sesuai ketentuan. Menurut data BPS disebutkan bahwa pada tahun 2014 rata-rata jumlah raskin yang diterima oleh 20 persen rumah tangga dengan pengeluaran terendah di Jawa Tengah adalah sebanyak 5,60 kg padahal mereka seharusnya menerima $15 \mathrm{~kg}$ per bulan 
dan rata-rata harga yang dibayar untuk membeli raskin sebesar Rp. 2.070 per kg padahal mereka seharusnya membayar dengan harga Rp. 1.600 per $\mathrm{kg}$. Berdasarkan latar belakang dan rumusan masalah yang ada, maka penelitian ini memiliki tujuan menganalisis karakteristik penerima raskin di Provinsi Jawa Tengah.

Bank Dunia (BPS, 2009) menghitung garis kemiskinan dengan menggunakan pengeluaran konsumsi yang dikonversi ke dalam US\$ PPP. Tujuannya adalah agar dapat membandingkan tingkat kemiskinan antar negara. Ada 2 ukuran yang digunakan oleh Bank Dunia yaitu US\$ 1 PPP per kapita per hari dan US\$ 2 PPP per kapita per hari. Ukuran tersebut sekarang direvisi menjadi US\$1,25 PPP dan US\$2 PPP per kapita per hari.

Untuk mengukur kemiskinan, Badan Pusat Statistik (BPS, 2009) menggunakan konsep kemampuan memenuhi kebutuhan dasar (basic needs approach). Dengan pendekatan ini, kemiskinan dipandang sebagai ketidakmampuan dari sisi ekonomi untuk memenuhi kebutuhan dasar makanan dan bukan makanan yang diukur dari sisi pengeluaran. Garis kemiskinan dinyatakan dalam rupiah per kapita per bulan. Penduduk dikatakan miskin jika penduduk tersebut memiliki rata-rata pengeluaran per kapita per bulan di bawah garis kemiskinan.

Rumah tangga sasaran penerima manfaat (RTS-PM) yang berhak mendapatkan raskin adalah rumah tangga yang terdapat dalam daftar nama dan alamat untuk program raskin 2015, yang diterbitkan dari Basis Data Terpadu yang dikelola oleh Tim Nasional Percepatan Penanggulangan Kemiskinan (TNP2K) yang telah dimutakhirkan berdasarkan pelaporan hasil musyawarah desa/musyawarah kelurahan (mudes/muskel) tahun 2014 yang tertuang di dalam Formulir Rekapitulasi Pengganti (FRP) 2014 dan telah dilaporkan ke Sekretariat TNP2K sesuai tenggat yang telah ditetapkan, dan disahkan oleh Kemenko Kesra sesuai dengan kemampuan anggaran pemerintah sebanyak 15.530.897 RTS-PM, serta rumah tangga hasil pemutakhiran Daftar Penerima Manfaat (DPM) oleh musyawarah desa/ kelurahan/pemerintah setingkat pada tahun 2015.

Besaran pagu raskin nasional tahun 2015 yaitu 2,79 juta ton beras selama 12 bulan untuk 15.530.897 RTS-PM atau sebanyak 15 $\mathrm{kg} / \mathrm{RTS} / \mathrm{bulan}$ atau $180 \mathrm{~kg} / \mathrm{RTS} /$ tahun dengan Harga Tebus Raskin (HTR) sebesar Rp $1.600,00 / \mathrm{kg}$ di titik distribusi.

Penelitian-penelitian terdahulu yang menjadi acuan dalam penulisan ini dapat dilihat pada tabel 4.

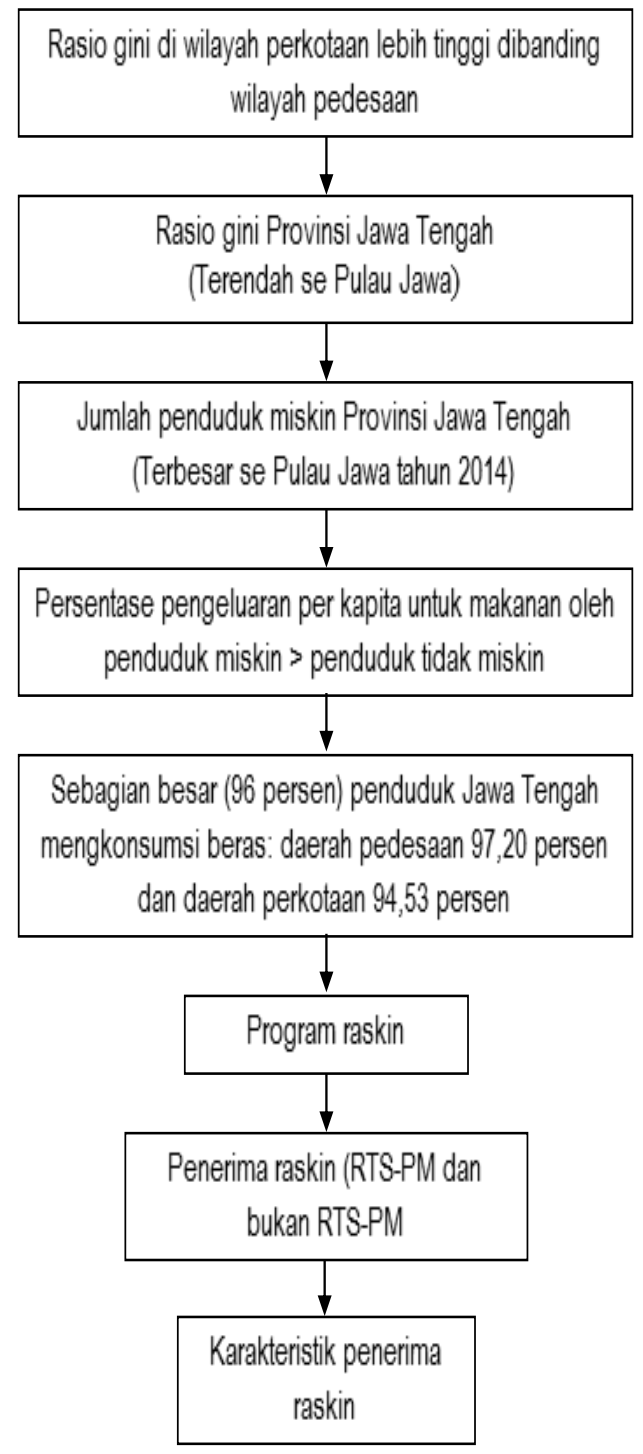

Gambar 2. Kerangka Pemikiran Teoritis 
Tabel 4. Penelitian Terdahulu yang Menjadi Acuan

\begin{tabular}{|c|c|c|c|c|}
\hline No & Judul Penelitian & Nama Peneliti & Alat Analisis & Hasil Penelitian \\
\hline 1 & $\begin{array}{l}\text { Who Benefits from } \\
\text { Social Assistance in } \\
\text { the Philippines? } \\
\text { Evidence from the } \\
\text { Latest National } \\
\text { Household Surveys, } \\
2012\end{array}$ & $\begin{array}{c}\text { Luisa } \\
\text { Fernandez } \\
\text { and Rashiel } \\
\text { Velarde }\end{array}$ & $\begin{array}{c}\text { Benefit Incidence } \\
\text { Analysis }\end{array}$ & $\begin{array}{c}\text { Program Subsidi } \\
\text { Langsung Bersyarat } \\
\text { (CCT) dan Program } \\
\text { Subsidi Beras bersifat } \\
\text { progresif. }\end{array}$ \\
\hline 2 & $\begin{array}{l}\text { Analisis } \\
\text { Efektivitas } \\
\text { Program Raskin } \\
\text { dan Kepuasan } \\
\text { Rumah Tangga } \\
\text { Penerima Manfaat } \\
\text { di DKI Jakarta, } \\
2010\end{array}$ & Rini Andrida & $\begin{array}{l}\text { Deskriptif dengan } \\
\text { pendekatan survei }\end{array}$ & $\begin{array}{l}\text { Sebagian besar RTS } \\
\text { menganggap bahwa } \\
\text { sasaran penerima } \\
\text { Program Raskin sudah } \\
\text { tepat dan terhadap } \\
\text { jumlah beras yang } \\
\text { dibagikan juga sudah } \\
\text { tepat. Ketepatan harga } \\
\text { raskin menurut sebagian } \\
\text { RTS adalah sudah tepat. }\end{array}$ \\
\hline 3 & $\begin{array}{l}\text { Analisis } \\
\text { Efektivitas } \\
\text { Kebijakan Publik } \\
\text { Memihak } \\
\text { Masyarakat } \\
\text { Miskin: Studi } \\
\text { Kasus } \\
\text { Pelaksanaan } \\
\text { Program Raskin di } \\
\text { Provinsi Jawa } \\
\text { Barat pada Tahun } \\
\text { 2007, 2008 }\end{array}$ & $\begin{array}{l}\text { M. Parulian } \\
\text { Hutagaol dan } \\
\text { Alla Asmara }\end{array}$ & $\begin{array}{c}\text { Deskriptif } \\
\text { kualitatif dan } \\
\text { deskriptif } \\
\text { kuantitatif }\end{array}$ & \begin{tabular}{lr}
\multicolumn{2}{l}{ Penerima raskin bukan } \\
hanya Rumah Tangga \\
Miskin (RTM) yang \\
terdaftar tetapi juga \\
rumah tangga lainnya \\
yang tidak terdaftar. \\
Bahkan banyak dari \\
mereka & ini \\
sesungguhnya tidak \\
tergolong miskin.
\end{tabular} \\
\hline 4 & $\begin{array}{l}\text { Studi } \\
\text { Implementasi } \\
\text { Program Raskin di } \\
\text { Wilayah } \\
\text { Kelurahan } \\
\text { Gajahmungkur, } \\
\text { Kecamatan } \\
\text { Gajahmungkur, } \\
\text { Kota Semarang, } \\
2009\end{array}$ & $\begin{array}{l}\text { Mariyam } \\
\text { Musawa }\end{array}$ & Deskriptif & $\begin{array}{l}\text { Program Beras untuk } \\
\text { Rumah Tangga Miskin } \\
\text { masih memunculkan } \\
\text { beberapa permasalahan, } \\
\text { di antaranya adalah } \\
\text { pendistribusian belum } \\
\text { tepat sasaran, belum } \\
\text { tepat jumlah dan belum } \\
\text { tepat waktu, sehingga } \\
\text { kurang bermanfaat bagi } \\
\text { penerima. }\end{array}$ \\
\hline
\end{tabular}




\begin{tabular}{|c|c|c|c|c|}
\hline No & Judul Penelitian & Nama Peneliti & Alat Analisis & Hasil Penelitian \\
\hline 5 & \begin{tabular}{lr}
\multicolumn{2}{c}{ Studi } \\
Implementasi \\
Penanggulangan \\
Kemiskinan \\
dalam & Rangka \\
Program & Beras \\
Keluarga & Miskin \\
(Raskin) & di \\
Kecamatan & Pati \\
Kabupaten & Pati, \\
2005
\end{tabular} & $\begin{array}{c}\text { Arizal } \\
\text { Jauhariansah }\end{array}$ & 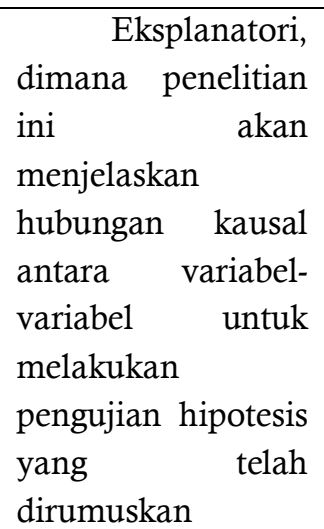 & $\begin{array}{lr}\text { Pelaksanaan } & \text { Program } \\
\text { Beras Keluarga } & \text { Miskin } \\
\text { (raskin) di Kecamatan } \\
\text { Pati dalam kategori } \\
\text { rendah atau belum } \\
\text { optimal. }\end{array}$ \\
\hline 6 & $\begin{array}{lr}\text { Studi } & \text { Evaluasi } \\
\text { Kinerja } & \text { Program } \\
\text { Raskin } & \text { di } \\
\text { Kecamatan } & \text { Suruh } \\
\text { Kabupaten } & \\
\text { Semarang, } 2004\end{array}$ & $\begin{array}{c}\text { Itsna } \\
\text { Mauliyawati, } \\
\text { dkk }\end{array}$ & $\begin{array}{l}\text { Evaluasi formatif } \\
\text { yaitu evaluasi } \\
\text { setelah program itu } \\
\text { dijalankan dengan } \\
\text { cara melihat dan } \\
\text { meneliti } \\
\text { pelaksanaan suatu } \\
\text { program, mencari } \\
\text { umpan balik untuk } \\
\text { memperbaiki } \\
\text { pelaksanaan } \\
\text { program tersebut }\end{array}$ & 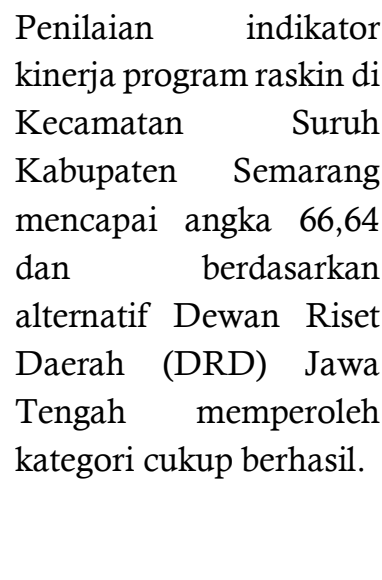 \\
\hline 7 & $\begin{array}{l}\text { Efektivitas } \\
\text { Pelaksanaan } \\
\text { Raskin, } 2007\end{array}$ & $\begin{array}{c}\text { Sulton } \\
\text { Mawardi, dkk }\end{array}$ & $\begin{array}{l}\text { Tinjauan dokumen } \\
\text { dan analisis data } \\
\text { sekunder } \\
\text { (metaevaluasi) }\end{array}$ & $\begin{array}{lr}\text { Banyak kasus, } \\
\text { musyawarah desa } \\
\text { (mudes) dalam rangka } \\
\text { menentukan rumah } \\
\text { tangga penerima raskin, } \\
\text { padar akhirnya } \\
\text { menghasilkan keputusan } \\
\text { raskin dibagi rata kepada } \\
\text { jumlah rumah tangga } \\
\text { yang lebih banyak atau } \\
\text { kepada seluruh rumah } \\
\text { tangga. }\end{array}$ \\
\hline
\end{tabular}




\section{METODE PENELITIAN}

Variabel yang digunakan dalam penelitian ini adalah (1) Penduduk miskin adalah penduduk yang memiliki rata-rata pengeluaran per kapita per bulan di bawah garis kemiskinan (GK). (2) Pengeluaran per kapita adalah biaya yang dikeluarkan untuk konsumsi semua anggota rumah tangga selama sebulan dibagi dengan banyaknya anggota rumah tangga (BPS, 2014). (3) Rumah tangga sasaran program raskin meliputi rumah tangga sangat miskin (SM), rumah tangga miskin $(\mathrm{M})$, rumah tangga hampir miskin (HM), dan rumah tangga rentan miskin lainnya (RML) (Kementerian Koordinator Bidang Kesejahteraan Rakyat, 2014).

a. Rumah tangga sangat miskin (SM) adalah rumah tangga yang memiliki pengeluaran per kapita/bulan $<=0,8 \mathrm{GK}$.

b. Rumah tangga miskin (M) adalah rumah tangga yang memiliki pengeluaran per kapita/bulan $>0,8 \mathrm{GK}$ dan $<=1 \mathrm{GK}$.

c. Rumah tangga hampir miskin (HM) adalah rumah tangga yang memiliki pengeluaran per kapita/bulan $>1$ GK dan $<=1,2$ GK.

d. Rumah tangga rentan miskin lainnya (RML) adalah rumah tangga yang memiliki pengeluaran per kapita/bulan $>1,2$ GK dan $<=1,6 \mathrm{GK}$.

Data yang digunakan adalah data sosial ekonomi rumah tangga sampel Survei Sosial Ekonomi Nasional (Susenas) tahun 2015 dari BPS Provinsi Jawa Tengah baik Kor maupun Konsumsi/Pengeluaran.

Sumber: BPS, 2015.

Rumah tangga yang bukan merupakan sasaran program raskin yaitu rumah tangga tidak miskin (TM) adalah rumah tangga yang memiliki pengeluaran per kapita/bulan > 1,6 GK.

Teknis analisis yang digunakan dalam penelitian ini adalah Analisis Tabulasi Silang (Crosstab). Menurut Ghozali (2011), analisis tabulasi silang pada prinsipnya menyajikan data dalam bentuk tabulasi yang meliputi baris dan kolom. Analisis tabulasi silang dilakukan terhadap data sampel rumah tangga penerima raskin dengan beberapa variabel yaitu (a) Status wilayah (perkotaan dan pedesaan). (b) Kategori rumah tangga menurut kemiskinan (sangat miskin (SM), miskin (M), hampir miskin (HM), rentan miskin lainnya (RML), dan tidak miskin (TD). (c) Jumlah anggota rumah tangga. (d) Pendidikan tertinggi yang ditamatkan kepala rumah tangga. (e) Status kepemilikan bangunan tempat tinggal yang ditempati. (f) Luas lantai per kapita. (g) Kepemilikan aset rumah tangga. (h) Status pekerjaan dari penghasilan yang terbesar. (i) Lapangan usaha pekerjaan dari penghasilan yang terbesar. (j) Jumlah raskin yang diterima/dibeli. (k) Harga tebus raskin yang dibayarkan. Perbedaan tingkat tinggi antara tes akan menghasilkan sedikit kovarian dalam kinerja meskipun dirancang untuk menilai kemampuan yang sama (Cheke dan Nichole, 2015)

\section{HASIL DAN PEMBAHASAN}

Berdasarkan data kemiskinan BPS (2016) bahwa GK untuk wilayah perkotaan di Provinsi Jawa Tengah tahun 2015 adalah sebesar Rp. 299.011,- sedangkan GK untuk wilayah pedesaan adalah sebesar Rp. 296.864,-. Sehingga dari data pengeluaran per kapita per bulan masing-masing rumah tangga dan GK tersebut maka rumah tangga sampel dapat dikategorikan tingkat kemiskinannya. Adapun Jumlah Rumah Tangga Sampel Menurut Kategori Kemiskinan, dapat dilihat pada tabel 5 .

Pembahasan dan analisis di dalam penelitian ini dibatasi hanya untuk rumah tangga yang menerima/membeli raskin pada bulan Januari dan Februari tahun 2015 di Provinsi Jawa Tengah. Rumah tangga sampel Susenas 2015 sebanyak 26.655 yang menerima/membeli raskin pada tahun 2015 adalah sebanyak 15.254 rumah tangga dan untuk selanjutnya yang dibahas dan dianalisis di dalam penelitian ini adalah rumah tangga penerima/pembeli raskin tersebut. Rumah tangga yang menerima/membeli raskin ini untuk selanjutnya disebut sebagai rumah tangga penerima raskin.

Rumah tangga penerima raskin yang diteliti di sini adalah rumah tangga yang dalam kenyataannya menerima raskin dan belum tentu merupakan RTS-PM yang disahkan oleh pemerintah sebagai penerima raskin yang sah. 
Tabel 5. Jumlah Rumah Tangga Sampel Menurut Kategori Kemiskinan

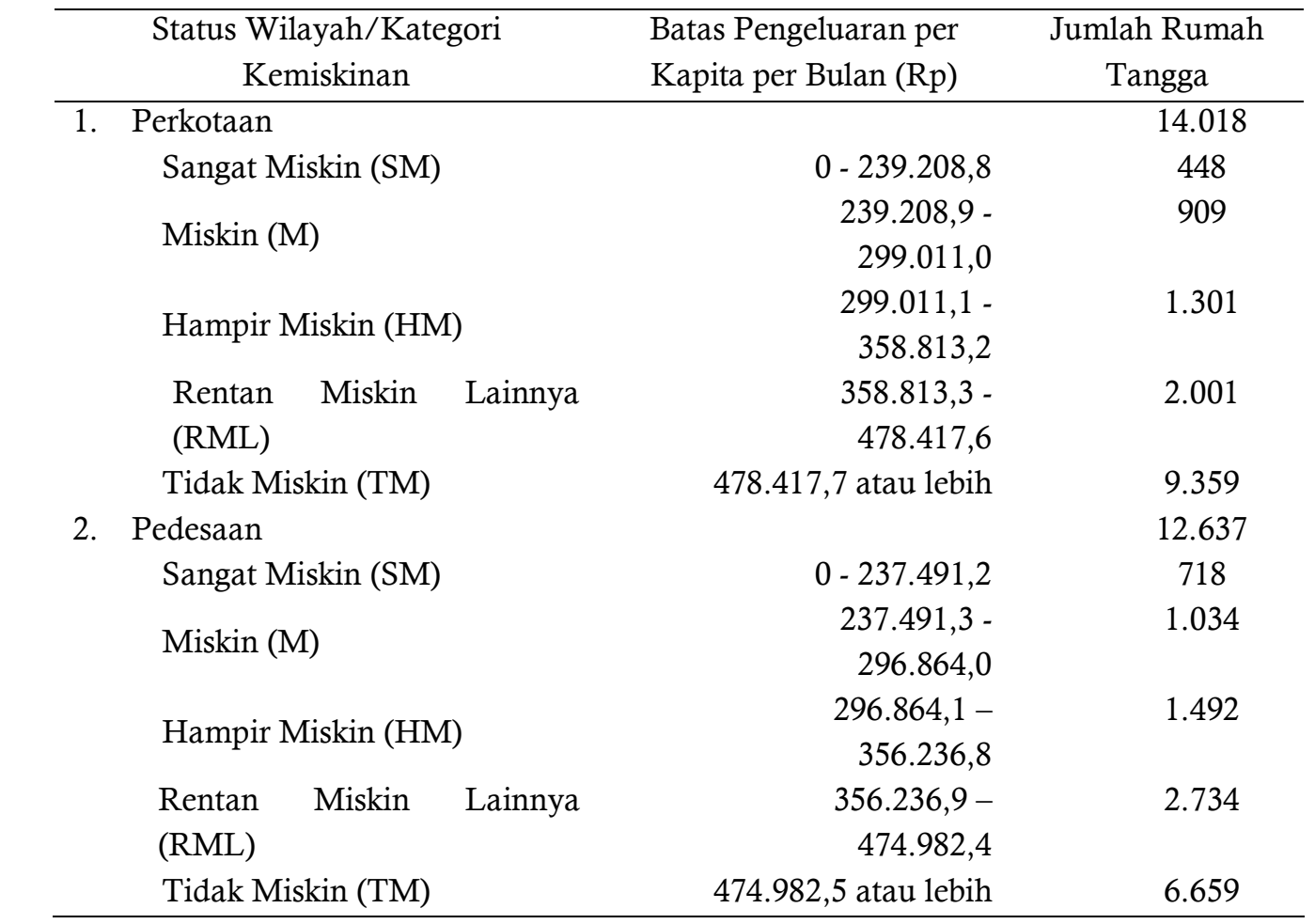

Sumber : Data Susenas 2015 Diolah

Tabel 6. Persentase Rumah Tangga di Provinsi Jawa Tengah Menurut Apakah Menerima/Membeli

\begin{tabular}{lccc}
\multicolumn{4}{c}{ Raskin?, 2015 } \\
\hline \multirow{2}{*}{ Status Wilayah/ Kategori Kemiskinan } & $\begin{array}{c}\text { Apakah Menerima/Membeli } \\
\text { Tahun 2015? }\end{array}$ & Raskin pada \\
& Iya & Tidak & Jumlah \\
\hline Perkotaan & $46,9 \%$ & $53,1 \%$ & $100,0 \%$ \\
-Sangat Miskin (SM) & $3,1 \%$ & $0,6 \%$ & $3,7 \%$ \\
-Miskin (M) & $4,9 \%$ & $1,9 \%$ & $6,9 \%$ \\
-Hampir Miskin (HM) & $6,6 \%$ & $2,9 \%$ & $9,5 \%$ \\
-Rentan Miskin Lainnya (RML) & $9,7 \%$ & $5,0 \%$ & $14,8 \%$ \\
-Tidak Miskin (TM) & $22,5 \%$ & $42,7 \%$ & $65,2 \%$ \\
Pedesaan & $72,9 \%$ & $27,1 \%$ & $100,0 \%$ \\
-Sangat Miskin (SM) & $4,7 \%$ & $0,8 \%$ & $5,5 \%$ \\
-Miskin (M) & $6,4 \%$ & $1,6 \%$ & $8,0 \%$ \\
-Hampir Miskin (HM) & $9,6 \%$ & $2,2 \%$ & $11,8 \%$ \\
-Rentan Miskin Lainnya (RML) & $17,5 \%$ & $4,4 \%$ & $21,9 \%$ \\
-Tidak Miskin (TM) & $34,7 \%$ & $18,1 \%$ & $52,8 \%$ \\
\hline
\end{tabular}

Sumber : Data Susenas 2015 Diolah

Berdasarkan tabel 6 diketahui bahwa masih ada rumah tangga yang seharusnya berhak menerima raskin (rumah tangga dengan kategori $\mathrm{SM}, \mathrm{M}, \mathrm{HM}$, dan RML) namun tidak menerima raskin dan sebaliknya masih ada rumah tangga yang seharusnya tidak berhak menerima raskin namun menerima raskin yaitu rumah tangga dengan kategori tidak miskin (TD). Untuk 
wilayah perkotaan masih ada 10,4 persen rumah tangga yang menurut kategori kemiskinan seharusnya menerima raskin namun tidak menerima raskin dan terdapat 22,5 persen rumah tangga yang tidak miskin namun menerima raskin. Sedangkan untuk wilayah pedesaan masih ada 9 persen rumah tangga yang menurut kategori kemiskinan seharusnya menerima raskin namun tidak menerima raskin dan sebaliknya terdapat 34,7 persen rumah tangga yang tidak miskin namun menerima raskin. Hal ini disebabkan karena banyak wilayah yang masih menerapkan sistem membagi rata ke banyak rumah tangga dalam pembagian raskin, sehingga rumah tangga yang tidak miskin yang seharusnya tidak berhak menerima raskin tetapi menerima raskin. Rumah tangga yang seharusnya berhak menerima raskin tetapi tidak menerima raskin bisa disebabkan oleh memang tidak menerima distribusi raskin dari pelaksana distribusi raskin di desa/kelurahan setempat atau rumah tangga tersebut tidak mempunyai uang untuk membayar/menebus raskin.

Sasaran program raskin adalah rumah tangga, sehingga berapapun jumlah anggota rumah tangga dari rumah tangga penerima raskin, masing-masing rumah tangga akan menerima sejumlah raskin yang sama untuk wilayah yang sama. Semakin banyak jumlah anggota rumah tangga dari rumah tangga penerima raskin maka semakin tinggi manfaat program raskin karena berhasil menjangkau lebih banyak penduduk miskin.

Tabel 7 menunjukkan bahwa 48 persen rumah tangga penerima raskin di wilayah perkotaan adalah rumah tangga tidak miskin atau tidak layak menerima raskin, dan hanya 52 persen rumah tangga penerima raskin yang memang layak menerima raskin. Sedangkan di wilayah pedesaan terdapat 47,6 persen rumah tangga penerima raskin yang tidak miskin dan hanya 52,3 persen rumah tangga penerima raskin yang layak menerima raskin.

Tabel 7. Persentase Rumah Tangga Penerima/Pembeli Raskin di Provinsi Jawa Tengah Menurut Jumlah Anggota Rumah Tangga, 2015

\begin{tabular}{|c|c|c|c|c|}
\hline \multirow[b]{2}{*}{ Status Wilayah/ Kategori Kemiskinan } & \multicolumn{3}{|c|}{ Jumlah Anggota Rumah Tangga } & \multirow[b]{2}{*}{ Jumlah } \\
\hline & $1-2$ orang & 3-4 orang & $\begin{array}{l}5 \text { orang atau } \\
\text { lebih }\end{array}$ & \\
\hline Perkotaan & $20,4 \%$ & $49,4 \%$ & $30,3 \%$ & $\begin{array}{l}100,0 \\
\%\end{array}$ \\
\hline -Sangat Miskin (SM) & $1,4 \%$ & $2,3 \%$ & $3,0 \%$ & $6,7 \%$ \\
\hline -Miskin (M) & $2,1 \%$ & $4,5 \%$ & $4,0 \%$ & $10,5 \%$ \\
\hline -Hampir Miskin (HM) & $2,2 \%$ & $6,9 \%$ & $4,9 \%$ & $14,0 \%$ \\
\hline -Rentan Miskin Lainnya (RML) & $3,2 \%$ & 10,5 & $7,1 \%$ & $20,8 \%$ \\
\hline -Tidak Miskin (TM) & $11,5 \%$ & $\begin{array}{l}\% \\
\%\end{array}$ & $11,3 \%$ & $48,0 \%$ \\
\hline Pedesaan & $22,6 \%$ & 53,2 & $24,2 \%$ & $100,0 \%$ \\
\hline -Sangat Miskin (SM) & $1,6 \%$ & $2,3 \%$ & $2,5 \%$ & $6,4 \%$ \\
\hline -Miskin (M) & $1,9 \%$ & $4,1 \%$ & $2,8 \%$ & $8,8 \%$ \\
\hline -Hampir Miskin (HM) & $2,3 \%$ & $6,5 \%$ & $4,4 \%$ & $13,2 \%$ \\
\hline -Rentan Miskin Lainnya (RML) & $4,8 \%$ & 13,0 & $6,1 \%$ & $24,0 \%$ \\
\hline -Tidak Miskin (TM) & $12,1 \%$ & 27,2 & $8,3 \%$ & $47,6 \%$ \\
\hline
\end{tabular}

Sumber : Data Susenas 2015 Diolah

Sebagian besar rumah tangga penerima raskin mempunyai jumlah anggota rumah tangga sebanyak 3-4 orang baik di wilayah perkotaan maupun pedesaan. Hal ini karena sebagian besar rumah tangga di Provinsi Jawa Tengah mempunyai jumlah anggota rumah tangga 3-4 orang juga. Namun demikian, sebagian besar rumah tangga penerima raskin yang masuk 
kategori sangat miskin memiliki jumlah anggota rumah tangga 5 orang atau lebih, baik di wilayah perkotaan maupun pedesaan. Hal ini menunjukkan bahwa rumah tangga sangat miskin mempunyai jumlah tanggungan anggota rumah tangga yang lebih banyak sehingga beban biaya hidup mereka meningkat.

Pendidikan tertinggi yang ditamatkan oleh seseorang sangat berpengaruh terhadap tingkat kesejahteraan orang tersebut. Demikian juga untuk tingkat pendidikan tertinggi yang ditamatkan oleh kepala rumah tangga juga berpengaruh terhadap kesejahteraan rumah tangga tersebut. Semakin tinggi tingkat pendidikan tertinggi yang ditamatkan oleh kepala rumah tangga maka tingkat kesejahteraan suatu rumah tangga juga cenderung semakin tinggi. Dari sisi pendidikan tertinggi yang ditamatkan oleh kepala rumah tangga, rumah tangga penerima raskin bervariasi dari tidak/belum pernah sekolah sampai dengan lulus D4/S1. Namun demikian, yang terbanyak adalah mereka yang tamat SD atau sederajat yaitu sebanyak 36,7 persen untuk wilayah perkotaan dan 42,3 persen untuk wilayah pedesaan dan yang tidak/belum tamat SD atau sederajat yaitu sebanyak 23,4 persen untuk wilayah perkotaan dan 25,8 persen untuk wilayah pedesaan. Adapun Persentase Rumah Tangga Penerima/Pembeli Raskin di Provinsi Jawa Tengah Menurut Pendidikan Tertinggi yang Ditamatkan Kepala Rumah Tangga tahun 2015, dapat dilihat pada tabel 8 .

Pendidikan tertinggi yang ditamatkan oleh kepala rumah tangga penerima raskin di wilayah perkotaan lebih tinggi jika dibandingkan dengan di wilayah pedesaan. Kepala rumah tangga penerima raskin di wilayah perkotaan yang tidak tamat SMP adalah sebanyak 69,8 persen sedangkan untuk di wilayah pedesaan mencapai 79,6 persen. Hal ini dikarenakan tingkat pendidikan masyarakat perkotaan secara umum lebih tinggi dari masyarakat pedesaan di mana di wilayah perkotaan sarana dan prasarana pendidikan lebih memadai daripada di wilayah pedesaan.

Sebagian besar pendidikan tertinggi kepala rumah tangga penerima raskin adalah masih rendah yaitu tidak sampai tamat SMP. Namun demikian masih ada kepala rumah tangga penerima raskin yang mempunyai pendidikan tertinggi diploma bahkan sarjana meskipun sedikit, yaitu untuk wilayah perkotaan sebanyak 1 persen dan untuk wilayah pedesaan sebanyak 0,8 persen. Sebagian besar dari mereka adalah termasuk rumah tangga tidak miskin dan hanya sebagian kecil yang termasuk rumah tangga rentan miskin. Adapun Persentase Rumah Tangga Penerima/Pembeli Raskin di Provinsi Jawa Tengah Menurut Status Kepemilikan Bangunan Tempat Tinggal yang Ditempati tahun 2015 dapat dilihat pada tabel 9.

Bangunan tempat tinggal adalah tempat berlindung suatu individu atau keluarga sehingga mereka merasa aman dan nyaman di dalamnya. Kondisi bangunan tempat tinggal menentukan tingkat kesejahteraan orang yang tinggal di dalamnya. Berdasarkan tabel 8 diketahui bahwa sebagian besar rumah tangga penerima raskin sudah memiliki bangunan tempat tinggal/rumah sendiri. Sehingga mereka tidak perlu mengeluarkan uang untuk biaya sewa atau kontrak rumah sebagai tempat tinggal. Rumah tangga penerima raskin di wilayah perkotaan yang menempati rumah milik sendiri adalah sebanyak 88,9 persen sedangkan di wilayah pedesaan sebanyak 96,1 persen.

Rumah tangga penerima raskin yang tidak menempati bangunan tempat tinggal/rumah milik sendiri di wilayah perkotaan sebanyak 11,1 persen, sedangkan di wilayah pedesaan sebanyak 3,9 persen. Untuk memenuhi kebutuhan tempat tinggal mereka bisa sewa, kontrak, atau bebas sewa. Jika mereka harus sewa atau kontrak maka mereka masih harus mengeluarkan uang untuk membayar biaya sewa atau kontrak yang menambah beban pengeluaran rumah tangga. 
Tabel 8. Persentase Rumah Tangga Penerima/Pembeli Raskin di Provinsi Jawa Tengah Menurut Pendidikan Tertinggi yang Ditamatkan Kepala Rumah Tangga, 2015

\begin{tabular}{|c|c|c|c|c|c|c|}
\hline \multirow[b]{2}{*}{ Status Wilayah/Kategori Kemiskinan } & \multicolumn{6}{|c|}{ Pendidikan Tertinggi yang Ditamatkan Kepala Rumah Tangga } \\
\hline & $\begin{array}{l}\text { Tidak/be lum } \\
\text { pernah sekolah }\end{array}$ & \multicolumn{2}{|c|}{$\begin{array}{l}\text { tamat } \\
\text { sederajat }\end{array}$} & $\begin{array}{l}\text { Tamat } \\
\text { sederajat }\end{array}$ & $\begin{array}{l}\text { Tamat } \\
\text { sederajat }\end{array}$ & SMP \\
\hline Perkotaan & $9,7 \%$ & \multicolumn{2}{|c|}{$23,4 \%$} & $36,7 \%$ & \multicolumn{2}{|l|}{$15,8 \%$} \\
\hline -Sangat Miskin (SM) & $1,3 \%$ & \multicolumn{2}{|l|}{$2,1 \%$} & $2,1 \%$ & \multicolumn{2}{|l|}{$0,7 \%$} \\
\hline -Miskin (M) & $1,6 \%$ & \multicolumn{2}{|l|}{$2,8 \%$} & $3,9 \%$ & \multicolumn{2}{|l|}{$1,4 \%$} \\
\hline -Hampir Miskin (HM) & $1,4 \%$ & \multicolumn{2}{|l|}{$3,5 \%$} & $5,3 \%$ & \multicolumn{2}{|l|}{$2,1 \%$} \\
\hline -Rentan Miskin Lainnya (RML) & $1,7 \%$ & \multicolumn{2}{|l|}{$5,2 \%$} & $7,8 \%$ & \multicolumn{2}{|l|}{$3,4 \%$} \\
\hline -Tidak Miskin (TM) & $3,7 \%$ & \multicolumn{2}{|l|}{$9,7 \%$} & $17,6 \%$ & \multicolumn{2}{|l|}{$8,3 \%$} \\
\hline Pedesaan & $11,5 \%$ & \multicolumn{2}{|l|}{$25,8 \%$} & $42,3 \%$ & \multicolumn{2}{|l|}{$12,5 \%$} \\
\hline -Sangat Miskin (SM) & $1,3 \%$ & \multicolumn{2}{|l|}{$2,4 \%$} & $2,2 \%$ & \multicolumn{2}{|l|}{$0,4 \%$} \\
\hline -Miskin (M) & $1,2 \%$ & \multicolumn{2}{|l|}{$2,7 \%$} & $3,7 \%$ & \multicolumn{2}{|l|}{$0,9 \%$} \\
\hline -Hampir Miskin (HM) & $1,7 \%$ & \multicolumn{2}{|l|}{$3,5 \%$} & $5,9 \%$ & \multicolumn{2}{|l|}{$1,3 \%$} \\
\hline -Rentan Miskin Lainnya (RML) & $2,9 \%$ & \multicolumn{2}{|l|}{$6,4 \%$} & $10,4 \%$ & \multicolumn{2}{|l|}{$2,9 \%$} \\
\hline -Tidak Miskin (TM) & $4,4 \%$ & \multicolumn{2}{|l|}{$10,9 \%$} & $20,3 \%$ & \multicolumn{2}{|l|}{$7,0 \%$} \\
\hline \multirow[b]{2}{*}{ Status Wilayah/ Kategori Kemiskinan } & \multicolumn{6}{|c|}{ Pendidikan Tertinggi yang Ditamatkan Kepala Rumah Tangga } \\
\hline & $\begin{array}{l}\text { Tamat } \\
\text { sederajat }\end{array}$ & SMA & $\begin{array}{l}\text { Tamat } \\
\text { D1/D2D } \\
3\end{array}$ & Tamat D4/S1 & \multicolumn{2}{|l|}{ Jumlah } \\
\hline Perkotaan & $13,4 \%$ & & $0,5 \%$ & $0,5 \%$ & $100,0 \%$ & \\
\hline -Sangat Miskin (SM) & $0,4 \%$ & & $0,0 \%$ & $0,0 \%$ & $6,7 \%$ & \\
\hline -Miskin (M) & $0,9 \%$ & & - & $0,0 \%$ & $10,5 \%$ & \\
\hline -Hampir Miskin (HM) & $1,6 \%$ & & $0,0 \%$ & $0,0 \%$ & $14,0 \%$ & \\
\hline -Rentan Miskin Lainnya (RML) & $2,5 \%$ & & $0,1 \%$ & $0,0 \%$ & $20,8 \%$ & \\
\hline -Tidak Miskin (TM) & $7,9 \%$ & & $0,3 \%$ & $0,5 \%$ & $48,0 \%$ & \\
\hline Pedesaan & $7,2 \%$ & & $0,3 \%$ & $0,5 \%$ & $100,0 \%$ & \\
\hline -Sangat Miskin (SM) & $0,1 \%$ & & - & - & $6,4 \%$ & \\
\hline -Miskin (M) & $0,5 \%$ & & - & $0,0 \%$ & $8,8 \%$ & \\
\hline -Hampir Miskin (HM) & $0,6 \%$ & & $0,0 \%$ & $0,0 \%$ & $13,2 \%$ & \\
\hline -Rentan Miskin Lainnya (RML) & $1,4 \%$ & & $0,1 \%$ & $0,1 \%$ & $24,0 \%$ & \\
\hline -Tidak Miskin (TM) & $4,5 \%$ & & $0,2 \%$ & $0,4 \%$ & $47,6 \%$ & \\
\hline
\end{tabular}

Sumber : Data Susenas 2015 Diolah

Tabel 9. Persentase Rumah Tangga Penerima/Pembeli Raskin di Provinsi Jawa Tengah Menurut Status Kepemilikan Bangunan Tempat Tinggal yang Ditempati, 2015

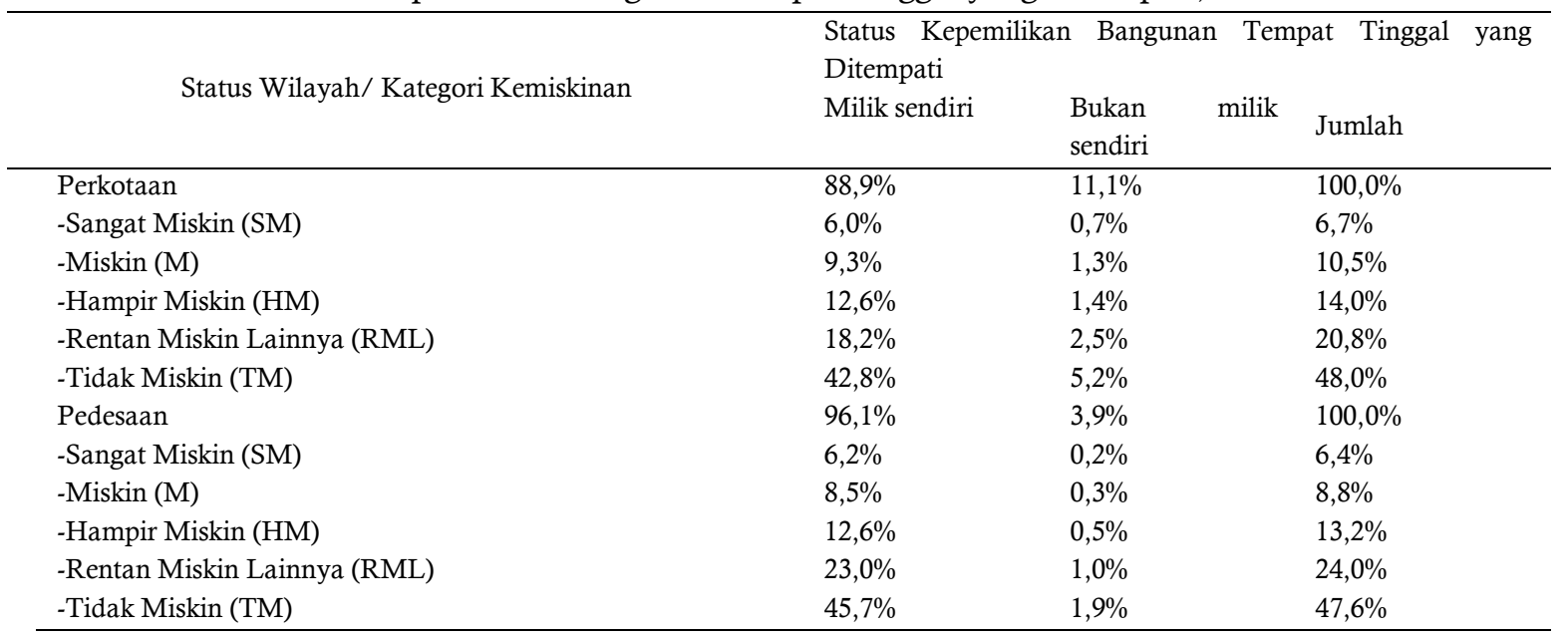

Sumber : Data Susenas 2015 Diolah 
Tabel 10. Persentase Rumah Tangga Penerima/Pembeli Raskin di Provinsi Jawa Tengah Menurut Luas Lantai per Kapita, 2015

\begin{tabular}{|c|c|c|c|c|c|}
\hline \multirow[b]{2}{*}{$\begin{array}{l}\text { Status Wilayah/ Kategori } \\
\text { Kemiskinan }\end{array}$} & \multicolumn{5}{|c|}{ Luas Lantai per Kapita } \\
\hline & $\begin{array}{l}8 \mathrm{~m} 2 \text { atau } \\
\text { kurang }\end{array}$ & $9-10 \mathrm{~m} 2$ & $11-15 \mathrm{~m} 2$ & $\begin{array}{l}16 \mathrm{~m} 2 \text { atau } \\
\text { lebih }\end{array}$ & Jumlah \\
\hline Perkotaan & $7,7 \%$ & $5,9 \%$ & $22,2 \%$ & $64,2 \%$ & $100,0 \%$ \\
\hline -Sangat Miskin (SM) & $0,9 \%$ & $0,6 \%$ & $1,9 \%$ & $3,3 \%$ & $6,7 \%$ \\
\hline -Miskin (M) & $1,0 \%$ & $0,9 \%$ & $2,9 \%$ & $5,7 \%$ & $10,5 \%$ \\
\hline -Hampir Miskin (HM) & $1,2 \%$ & $0,9 \%$ & $3,7 \%$ & $8,2 \%$ & $14,0 \%$ \\
\hline $\begin{array}{l}\text {-Rentan Miskin Lainnya } \\
\text { (RML) }\end{array}$ & $2,1 \%$ & $1,3 \%$ & $5,3 \%$ & $12,1 \%$ & $20,8 \%$ \\
\hline -Tidak Miskin (TM) & $2,5 \%$ & $2,1 \%$ & $8,5 \%$ & $34,9 \%$ & $48,0 \%$ \\
\hline Pedesaan & $3,2 \%$ & $3,8 \%$ & $18,5 \%$ & $74,5 \%$ & $100,0 \%$ \\
\hline -Sangat Miskin (SM) & $0,5 \%$ & $0,5 \%$ & $1,6 \%$ & $3,8 \%$ & $6,4 \%$ \\
\hline -Miskin (M) & $0,4 \%$ & $0,5 \%$ & $1,8 \%$ & $6,2 \%$ & $8,8 \%$ \\
\hline -Hampir Miskin (HM) & $0,3 \%$ & $0,7 \%$ & $3,4 \%$ & $8,7 \%$ & $13,2 \%$ \\
\hline $\begin{array}{l}\text {-Rentan Miskin Lainnya } \\
\text { (RML) }\end{array}$ & $0,9 \%$ & $1,0 \%$ & $4,8 \%$ & $17,3 \%$ & $24,0 \%$ \\
\hline -Tidak Miskin (TM) & $1,1 \%$ & $1,2 \%$ & $6,8 \%$ & $38,5 \%$ & $47,6 \%$ \\
\hline
\end{tabular}

Sumber : Data Susenas 2015 Diolah

Luas lantai dari bangunan tempat tinggal berpengaruh terhadap kenyamanan orang yang tinggal di dalamnya. Dalam BPS (2015) disebutkan bahwa Kementrian Kesehatan mensyaratkan rumah sehat dengan luas lantai per kapita minimal $8 \mathrm{~m} 2$ sedangan WHO mensyaratkan luas lantai per kapita untuk rumah sehat adalah minimal $10 \mathrm{~m} 2$.

Berdasarkan tabel 9 diketahui bahwa sebagian besar rumah tangga penerima raskin menempati bangunan tempat tinggal dengan luas lantai per kapita $16 \mathrm{~m} 2$ atau lebih, yaitu di wilayah perkotaan sebanyak 64,2 persen sedangkan untuk wilayah pedesaan terdapat 74,5 persen.

Tabel 8 dan tabel 9 menunjukkan bahwa dari 2 indikator perumahan yaitu status kepemilikan dan luas lantai per kapita diketahui bahwa kondisi perumahan di wilayah pedesaan lebih baik daripada di wilayah perkotaan. Di wilayah pedesaan lebih banyak rumah tangga penerima raskin yang menempati bangunan milik sendiri dan mempunyai luas lantai per kapita yang lebih luas jika dibanding rumah tangga penerima raskin di wilayah perkotaan. Hal ini dikarenakan biaya perumahan di wilayah perkotaan relatif lebih mahal dibandingkan di wilayah pedesaan, sehingga rumah tangga miskin yang merupakan penerima raskin di wilayah perkotaan sulit untuk menjangkaunya.

Aset merupakan salah satu harta kekayaan seseorang atau rumah tangga dan dapat menunjukkan tingkat kesejahteraan seseorang atau suatu rumah tangga. Jika seseorang atau suatu rumah tangga memiliki suatu aset tertentu maka orang atau rumah tangga tersebut menurut masyarakat sekitar dianggap lebih sejahtera jika dibanding orang atau rumah tangga yang tidak memiliki aset tersebut.

Lemari es atau kulkas bukan merupakan barang pokok yang harus dimiliki oleh suatu rumah tangga, selain harganya yang relatif mahal juga membutuhkan daya listrik yang banyak. Namun demikian sudah banyak rumah tangga penerima raskin yang memiliki lemari es atau kulkas. Hal ini dapat dilihat pada tabel 10 yang menunjukkan bahwa di wilayah perkotaan, rumah tangga penerima raskin yang memiliki lemari es atau kulkas adalah sebanyak 34,3 persen dan 22 persen di antaranya merupakan rumah tangga tidak miskin. Sedangkan untuk rumah tangga penerima raskin di wilayah pedesaan yang memiliki lemari es atau kulkas adalah sebanyak 20,9 persen dan 14,7 persen di antaranya merupakan rumah tangga tidak miskin. 
Tabel 11. Persentase Rumah Tangga Penerima/Pembeli Raskin di Provinsi Jawa Tengah Menurut Apakah Memiliki Lemari Es atau Kulkas?, 2015

\begin{tabular}{|c|c|c|c|}
\hline \multirow{2}{*}{ Status Wilayah/ Kategori Kemiskinan } & \multicolumn{3}{|c|}{ Apakah Memiliki Lemari Es atau Kulkas? } \\
\hline & Iya & Tidak & Jumlah \\
\hline Perkotaan & $34,3 \%$ & $65,7 \%$ & $100,0 \%$ \\
\hline -Sangat Miskin (SM) & $0,5 \%$ & $6,2 \%$ & $6,7 \%$ \\
\hline -Miskin (M) & $1,7 \%$ & $8,8 \%$ & $10,5 \%$ \\
\hline -Hampir Miskin (HM) & $3,8 \%$ & $10,2 \%$ & $14,0 \%$ \\
\hline -Rentan Miskin Lainnya (RML) & $6,3 \%$ & $14,5 \%$ & $20,8 \%$ \\
\hline -Tidak Miskin (TM) & $22,0 \%$ & $26,0 \%$ & $48,0 \%$ \\
\hline Pedesaan & $20,9 \%$ & $79,1 \%$ & $100,0 \%$ \\
\hline -Sangat Miskin (SM) & $0,3 \%$ & $6,1 \%$ & $6,4 \%$ \\
\hline -Miskin (M) & $0,6 \%$ & $8,2 \%$ & $8,8 \%$ \\
\hline -Hampir Miskin (HM) & $1,4 \%$ & $11,7 \%$ & $13,2 \%$ \\
\hline -Rentan Miskin Lainnya (RML) & $3,9 \%$ & $20,1 \%$ & $24,0 \%$ \\
\hline -Tidak Miskin (TM) & $14,7 \%$ & $32,9 \%$ & $47,6 \%$ \\
\hline
\end{tabular}

Sumber : Data Susenas 2015 Diolah

AC atau pendingin ruangan masih merupakan barang mewah apalagi bagi rumah tangga miskin. Selain harganya yang mahal dan membutuhkan daya listrik yang tinggi, fungsi AC juga masih dapat digantikan oleh kipas angin. Namun demikian ditemui rumah tangga penerima raskin yang memiliki AC meskipun jumlahnya sangat sedikit. Di wilayah perkotaan terdapat 0,7 persen rumah tangga penerima raskin yang memiliki AC yang terdiri dari 0,1 persen merupakan rumah tangga rentan miskin dan 0,6 persen yang merupakan rumah tangga tidak miskin. Rumah tangga tidak miskin tentunya merupakan rumah tangga yang tidak layak menerima distribusi raskin. Di wilayah pedesaan juga terdapat 0,2 persen rumah tangga penerima raskin yang memiliki AC yang terdiri dari 0,1 persen rumah tangga rentan miskin dan 0,1 persen rumah tangga tidak miskin.

Adapun Persentase Rumah Tangga Penerima/Pembeli Raskin di Provinsi Jawa Tengah Menurut Apakah Memiliki AC tahun 2015 dapat dilihat pada tabel 12 .

Pemanas air (water heater) digunakan sebagai pemanas air di kamar mandi. Aset ini tidak banyak dimiliki oleh suatu rumah tangga karena harganya yang mahal dan membutuhkan instalasi khusus di kamar mandi. Namun demikian ada rumah tangga penerima raskin yang memiliki pemanas air (water heater) dan sebagian rumah tangga tersebut merupakan rumah tangga miskin dan hampir miskin. Berdasarkan tabel 12 diketahui bahwa 1 persen dari rumah tangga penerima raskin di wilayah perkotaan memiliki pemanas air (water heater) di mana 0,4 persen adalah rumah tangga miskin, hampir miskin, dan rentan miskin lainnya serta selebihnya yaitu 0,7 persen adalah rumah tangga tidak miskin. Sedangkan di wilayah pedesaan terdapat 0,8 persen rumah tangga penerima raskin yang memiliki pemanas air (water heater) yang terdiri dari 0,2 persen adalah rumah tangga hampir miskin dan rentan miskin lainnya serta 0,6 persen lainnya merupakan rumah tangga tidak miskin. Adapun Persentase Rumah Tangga Penerima/Pembeli Raskin di Provinsi Jawa Tengah Menurut Apakah Memiliki Pemanas Air (Water Heater)? Tahun 2015 dapat dilihat pada tabel 13. 
Tabel 12. Persentase Rumah Tangga Penerima/Pembeli Raskin di Provinsi Jawa Tengah Menurut Apakah Memiliki AC?, 2015

\begin{tabular}{llll}
\hline \multirow{2}{*}{ Status Wilayah/ Kategori Kemiskinan } & \multicolumn{2}{l}{ Apakah Memiliki AC? } \\
& Iya & Tidak & Jumlah \\
\hline Perkotaan & $0,7 \%$ & $99,3 \%$ & $100,0 \%$ \\
-Sangat Miskin (SM) & - & $6,7 \%$ & $6,7 \%$ \\
-Miskin (M) & - & $10,5 \%$ & $10,5 \%$ \\
-Hampir Miskin (HM) & $0,0 \%$ & $14,0 \%$ & $14,0 \%$ \\
-Rentan Miskin Lainnya (RML) & $0,1 \%$ & $20,7 \%$ & $20,8 \%$ \\
-Tidak Miskin (TM) & $0,6 \%$ & $47,4 \%$ & $48,0 \%$ \\
Pedesaan & $0,2 \%$ & $99,8 \%$ & $100,0 \%$ \\
-Sangat Miskin (SM) & $0,0 \%$ & $6,4 \%$ & $6,4 \%$ \\
-Miskin (M) & - & $8,8 \%$ & $8,8 \%$ \\
-Hampir Miskin (HM) & $0,0 \%$ & $13,1 \%$ & $13,2 \%$ \\
-Rentan Miskin Lainnya (RML) & $0,1 \%$ & $23,9 \%$ & $24,0 \%$ \\
-Tidak Miskin (TM) & $0,1 \%$ & $47,4 \%$ & $47,6 \%$ \\
\hline
\end{tabular}

Sumber : Data Susenas 2015 Diolah

Tabel 13. Persentase Rumah Tangga Penerima/Pembeli Raskin di Provinsi Jawa Tengah Menurut Apakah Memiliki Pemanas Air (Water Heater)?, 2015

\begin{tabular}{llll}
\hline \multirow{2}{*}{ Status Wilayah/ Kategori Kemiskinan } & \multicolumn{3}{l}{ Apakah } \\
& Iya & Tidak & Jumliki Peman \\
\hline Perkotaan & $1,0 \%$ & $99,0 \%$ & $100,0 \%$ \\
-Sangat Miskin (SM) & - & $6,7 \%$ & $6,7 \%$ \\
-Miskin (M) & $0,1 \%$ & $10,4 \%$ & $10,5 \%$ \\
-Hampir Miskin (HM) & $0,1 \%$ & $13,9 \%$ & $14,0 \%$ \\
-Rentan Miskin Lainnya (RML) & $0,2 \%$ & $20,6 \%$ & $20,8 \%$ \\
-Tidak Miskin (TM) & $0,7 \%$ & $47,3 \%$ & $48,0 \%$ \\
Pedesaan & $0,8 \%$ & $99,2 \%$ & $100,0 \%$ \\
-Sangat Miskin (SM) & $0,0 \%$ & $6,4 \%$ & $6,4 \%$ \\
-Miskin (M) & $0,0 \%$ & $8,8 \%$ & $8,8 \%$ \\
-Hampir Miskin (HM) & $0,1 \%$ & $13,1 \%$ & $13,2 \%$ \\
-Rentan Miskin Lainnya (RML) & $0,1 \%$ & $23,9 \%$ & $24,0 \%$ \\
-Tidak Miskin (TM) & $0,6 \%$ & $47,0 \%$ & $47,6 \%$ \\
\hline
\end{tabular}

Sumber : Data Susenas 2015 Diolah

Emas/perhiasan merupakan salah satu aset untuk investasi yang fleksibel karena mudah untuk dibeli dan dijual kembali. Selain sebagai aset investasi, perhiasan dari emas juga dijadikan sebagai alat pemercantik diri seorang perempuan. Sehingga kepemilikan emas/perhiasan oleh masyarakat dianggap dapat menunjukkan tingkat kesejahteraan seseorang atau suatu rumah tangga. Semakin banyak memiliki emas/perhiasan maka orang atau rumah tangga tersebut dianggap semakin sejahtera. Namun demikian, sebagian orang menyimpan/memiliki emas/perhiasan bukan karena mempunyai uang yang lebih tetapi sebagai simpanan atau tabungan yang akan digunakan ketika mempunyai keperluan yang mendesak.

Di Provinsi Jawa Tengah, rumah tangga penerima raskin yang memiliki emas/perhiasan (minimal 10 gram) di wilayah perkotaan sebanyak 12,7 persen dan di wilayah pedesaan sebanyak 10,8 persen. Berdasarkan tabel 13 
diketahui bahwa rumah tangga penerima raskin yang memiliki emas/perhiasan (minimal 10 gram) menyebar di semua kategori kemiskinan. Sehingga di wilayah perkotaan pada kelompok rumah tangga sangat miskin ( 0,4 persen), miskin (0,5 persen), hampir miskin ( 1,3 persen), rentan miskin lainnya (2,2 persen), dan tidak miskin ( 8,3 persen) terdapat rumah tangga penerima raskin yang memiliki emas/perhiasan (minimal 10 gram). Sedangkan di wilayah pedesaan, rumah tangga penerima raskin yang memiliki emas/perhiasan (minimal 10 gram) untuk kategori rumah tangga sangat miskin sebanyak 0,2 persen, rumah tangga miskin sebanyak 0,4 persen, rumah tangga hampir miskin sebanyak 0,7 persen, rumah tangga rentan miskin lainnya sebanyak 1,9 persen, dan rumah tangga tidak miskin sebanyak 7,5 persen. Hal ini sering menjadi sorotan di masyarakat bahwa rumah tangga yang menerima bantuan dari pemerintah adalah salah sasaran, dikarenakan salah satu anggota rumah tangga tersebut memakai perhiasan. Namun demikian, ada rumah tangga yang dalam kenyataannya memang masuk kategori sangat miskin atau miskin atau hampir miskin atau rentan miskin lainnya yang menjadi sasaran dari program pengentasan kemiskinan oleh pemerintah memiliki emas/perhiasan. Adapun Persentase Rumah Tangga Penerima/Pembeli Raskin di Provinsi Jawa Tengah Menurut Apakah Memiliki Emas/Perhiasan (Minimal 10 Gram)? Tahun 2015 dapat di lihat pada tabel 14.

Yang dimaksud memiliki sepeda motor di dalam penelitian dapat berupa sepeda motor yang dibeli dengan cara tunai maupun kredit, sehingga pembayaran angsuran kredit sepeda motor tersebut bisa saja belum lunas. Uang muka untuk membeli sepeda motor secara kredit yang murah membuat masyarakat semakin mudah untuk membeli sepeda motor baru. Selain itu, memiliki sepeda motor di dalam penelitian ini juga tidak hanya yang memiliki sepeda motor baru namun juga termasuk memiliki sepeda motor yang sudah tua.

Rumah tangga penerima raskin yang memiliki sepeda motor hampir mendekati 70 persen. Di wilayah perkotaan terdapat 68,7 persen dan di wilayah pedesaan sebanyak 68,2 persen rumah tangga penerima raskin yang memiliki sepeda motor. Seperti halnya yang memiliki emas/perhiasan, rumah tangga ini juga menyebar ke semua kategori kemiskinan. Sehingga terdapat rumah tangga penerima raskin yang sangat miskin memiliki sepeda motor yaitu untuk di wilayah perkotaan sebanyak 2,3 persen sedangkan di wilayah pedesaan sebanyak 2,4 persen. Adapun Persentase Rumah Tangga Penerima/Pembeli Raskin di Provinsi Jawa Tengah Menurut Apakah Memiliki Sepeda Motor? Tahun 2015 dapat dilihat pada tabel 15 .

Mobil dapat berupa mobil untuk angkutan penumpang umum, angkutan barang, maupun mobil yang digunakan untuk keperluan rumah tangga. Mobil yang digunakan untuk angkutan penumpang umum dan angkutan barang merupakan mobil sebagai barang modal usaha. Seperti halnya sepeda motor, pengertian memiliki mobil di dalam penelitian ini juga mencakup mobil yang dibeli secara tunai maupun kredit baik sudah lunas maupun belum lunas dan baik mobil dengan kondisi bagus maupun kondisi jelek.

Rumah tangga penerima raskin di wilayah perkotaan yang memiliki mobil adalah sebanyak 1,9 persen $(0,1$ persen rumah tangga miskin, 0,1 persen rumah tangga hampir miskin, 0,2 persen rumah tangga rentan miskin lainnya, dan 1,6 persen rumah tangga tidak miskin), sedangkan di wilayah pedesaan yang memiliki mobil sebanyak 2,3 persen $(0,1$ persen rumah tangga hampir miskin, 0,2 persen rumah tangga rentan miskin lainnya, dan 1,9 persen rumah tangga tidak miskin). 
Tabel 14. Persentase Rumah Tangga Penerima/Pembeli Raskin di Provinsi Jawa Tengah Menurut Apakah Memiliki Emas/Perhiasan (Minimal 10 Gram)?, 2015

\begin{tabular}{llll}
\hline \multirow{2}{*}{ Status Wilayah/ Kategori Kemiskinan } & \multicolumn{3}{l}{ Apakah Memiliki Emas/Perhiasan (Minimal 10} \\
& Gram)? & Tidak & Jumlah \\
\hline Iya & $12,7 \%$ & $87,3 \%$ & $100,0 \%$ \\
\hline -Sangat Miskin (SM) & $0,4 \%$ & $6,3 \%$ & $6,7 \%$ \\
-Miskin (M) & $0,5 \%$ & $10,0 \%$ & $10,5 \%$ \\
-Hampir Miskin (HM) & $1,3 \%$ & $12,7 \%$ & $14,0 \%$ \\
-Rentan Miskin Lainnya (RML) & $2,2 \%$ & $18,6 \%$ & $20,8 \%$ \\
-Tidak Miskin (TM) & $8,3 \%$ & $39,7 \%$ & $48,0 \%$ \\
Pedesaan & $10,8 \%$ & $89,2 \%$ & $100,0 \%$ \\
-Sangat Miskin (SM) & $0,2 \%$ & $6,2 \%$ & $6,4 \%$ \\
-Miskin (M) & $0,4 \%$ & $8,4 \%$ & $8,8 \%$ \\
-Hampir Miskin (HM) & $0,7 \%$ & $12,4 \%$ & $13,2 \%$ \\
-Rentan Miskin Lainnya (RML) & $1,9 \%$ & $22,1 \%$ & $24,0 \%$ \\
-Tidak Miskin (TM) & $7,5 \%$ & $40,1 \%$ & $47,6 \%$ \\
\hline
\end{tabular}

Sumber : Data Susenas 2015 Diolah

Tabel 15. Persentase Rumah Tangga Penerima/Pembeli Raskin di Provinsi Jawa Tengah Menurut Apakah Memiliki Sepeda Motor?, 2015

\begin{tabular}{llll}
\hline \multirow{2}{*}{ Status Wilayah/ Kategori Kemiskinan } & \multicolumn{3}{l}{ Apakah Memiliki Sepeda Motor? } \\
& Iya & Tidak & Jumlah \\
\hline Perkotaan & $68,7 \%$ & $31,3 \%$ & $100,0 \%$ \\
-Sangat Miskin (SM) & $2,3 \%$ & $4,4 \%$ & $6,7 \%$ \\
-Miskin (M) & $5,9 \%$ & $4,7 \%$ & $10,5 \%$ \\
-Hampir Miskin (HM) & $9,3 \%$ & $4,7 \%$ & $14,0 \%$ \\
-Rentan Miskin Lainnya (RML) & $14,1 \%$ & $6,7 \%$ & $20,8 \%$ \\
-Tidak Miskin (TM) & $37,1 \%$ & $10,9 \%$ & $48,0 \%$ \\
Pedesaan & $68,2 \%$ & $31,8 \%$ & $100,0 \%$ \\
-Sangat Miskin (SM) & $2,4 \%$ & $4,0 \%$ & $6,4 \%$ \\
-Miskin (M) & $4,9 \%$ & $4,0 \%$ & $8,8 \%$ \\
-Hampir Miskin (HM) & $8,2 \%$ & $4,9 \%$ & $13,2 \%$ \\
-Rentan Miskin Lainnya (RML) & $15,9 \%$ & $8,1 \%$ & $24,0 \%$ \\
-Tidak Miskin (TM) & $36,8 \%$ & $10,7 \%$ & $47,6 \%$ \\
\hline
\end{tabular}

Sumber : Data Susenas 2015 Diolah 
Tabel 16. Persentase Rumah Tangga Penerima/Pembeli Raskin di Provinsi Jawa Tengah Menurut Apakah Memiliki Mobil?, 2015

\begin{tabular}{llll}
\hline \multirow{2}{*}{ Status Wilayah/ Kategori Kemiskinan } & \multicolumn{3}{l}{ Apakah Memiliki Mobil? } \\
\cline { 2 - 4 } & Iya & Tidak & Jumlah \\
\hline Perkotaan & $1,9 \%$ & $98,1 \%$ & $100,0 \%$ \\
-Sangat Miskin (SM) & - & $6,7 \%$ & $6,7 \%$ \\
-Miskin (M) & $0,1 \%$ & $10,5 \%$ & $10,5 \%$ \\
-Hampir Miskin (HM) & $0,1 \%$ & $13,9 \%$ & $14,0 \%$ \\
-Rentan Miskin Lainnya (RML) & $0,2 \%$ & $20,5 \%$ & $20,8 \%$ \\
-Tidak Miskin (TM) & $1,6 \%$ & $46,4 \%$ & $48,0 \%$ \\
Pedesaan & $2,3 \%$ & $97,7 \%$ & $100,0 \%$ \\
-Sangat Miskin (SM) & - & $6,4 \%$ & $6,4 \%$ \\
-Miskin (M) & $0,0 \%$ & $8,8 \%$ & $8,8 \%$ \\
-Hampir Miskin (HM) & $0,1 \%$ & $13,1 \%$ & $13,2 \%$ \\
-Rentan Miskin Lainnya (RML) & $0,2 \%$ & $23,8 \%$ & $24,0 \%$ \\
-Tidak Miskin (TM) & $1,9 \%$ & $45,6 \%$ & $47,6 \%$ \\
\hline Sumber : Da S & &
\end{tabular}

Sumber : Data Susenas 2015 Diolah

Penghasilan terbesar dari suatu rumah tangga adalah pendapatan yang diperoleh dari salah satu anggota rumah tangga (termasuk kepala rumah tangga) yang merupakan pendapatan paling besar. Sumber dari pendapatan tersebut dapat berasal dari bekerja atau sebagai penerima pendapatan (pemberian dari orang lain yang di luar anggota rumah tangga seperti anak/suami/istri yang bekerja di tempat lain, pensiunan, bunga deposito, atau pendapatan lain yang bukan dari bekerja).

Gambar 3 menunjukkan bahwa rumah tangga penerima raskin di wilayah perkotaan sebagian besar bekerja pada lapangan usaha pekerjaan sektor perdagangan, hotel, dan rumah makan yaitu sebanyak 21,3 persen, kemudian pada sektor industri pengolahan yaitu sebanyak 18,6 persen, dan sektor pertanian sebanyak 17,6 persen. Bekerja di sektor perdagangan, hotel, dan rumah makan contohnya adalah mereka yang bekerja sebagai pedagang (keliling, kaki lima, di rumah, atau kios), buruh/karyawan di toko, karyawan hotel/penginapan, pedagang bakso, pedagang es, karyawan warung makan, dan lainlain. Sedangkan yang bekerja di sektor industri pengolahan misalkan mereka yang bekerja sebagai karyawan pabrik, membuat gula merah, anyaman, dan lain-lain.

Sedangkan di wilayah pedesaan, rumah tangga penerima raskin sebagian besar bekerja di sektor pertanian yaitu sebanyak 42,8 persen atau hampir setengah dari seluruh rumah tangga penerima raskin di wilayah pedesaan adalah bekerja di sektor pertanian, kemudian bekerja di sektor konstruksi/bangunan sebanyak 13,7 persen, dan di sektor perdagangan, hotel, dan rumah makan sebanyak 13,4 persen. Mereka yang bekerja di sektor pertanian meliputi pertanian tanaman pangan, hortikultura, perkebunan, perikanan, peternakan, dan kehutanan. 


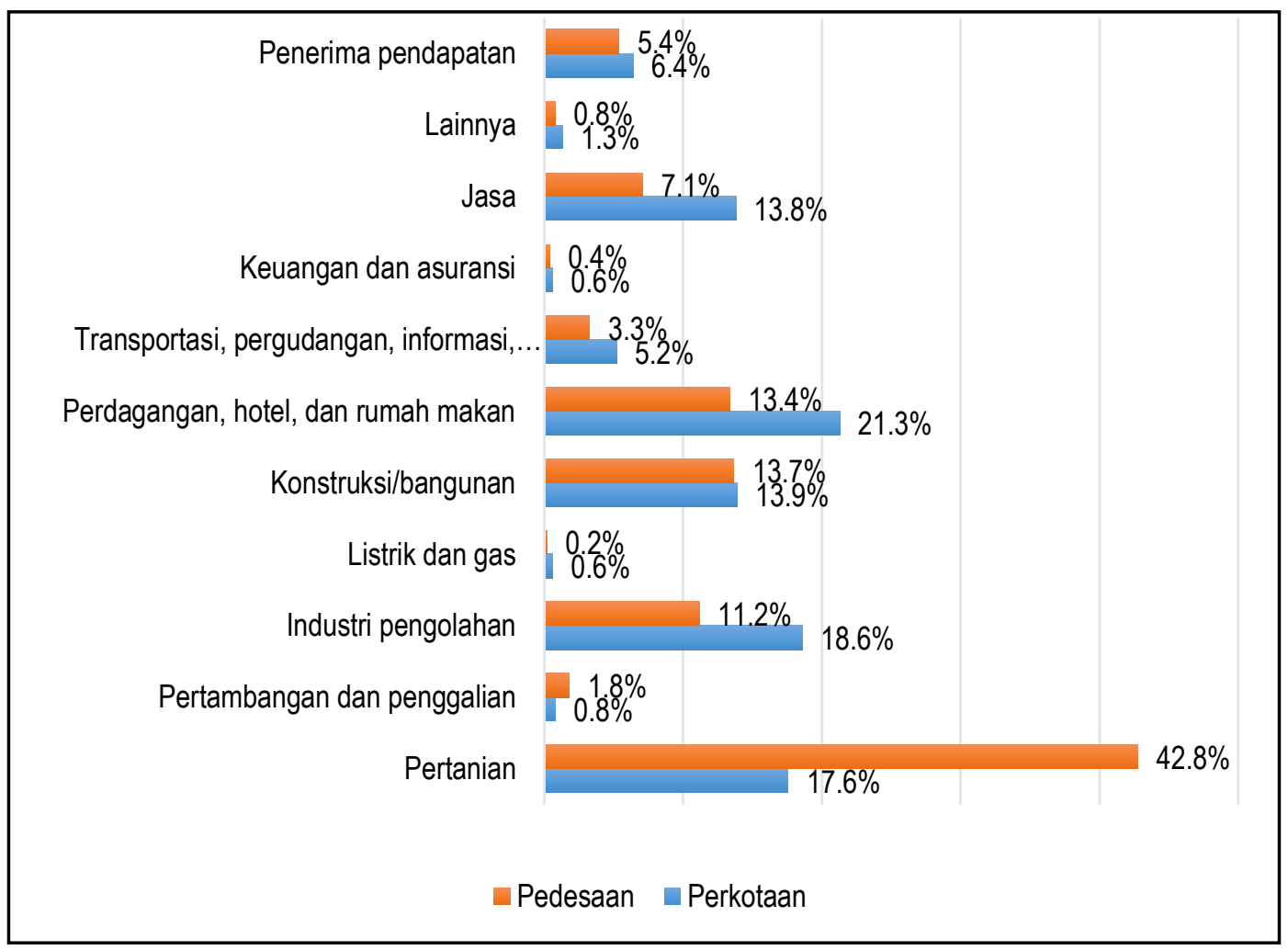

Gambar 3. Persentase Rumah Tangga Penerima/Pembeli Raskin di Provinsi Jawa Tengah Menurut Lapangan Usaha Pekerjaan dari Penghasilan yang Terbesar, 2015

Sumber : Data Susenas 2015 Diolah

Berdasarkan Pedoman Umum Raskin 2015 (Kementerian Koordinator Bidang Kesejahteraan Rakyat Republik Indonesia, 2014), bahwa alokasi raskin kepada rumah tangga sasaran program raskin adalah sebesar 15 $\mathrm{kg} / \mathrm{RTS} /$ bulan. Hasil pengolahan data Susenas 2015 dalam penelitian ini diketahui bahwa rumah tangga penerima raskin yang menerima raskin sebesar $15 \mathrm{~kg}$ hanya sebanyak 5,4 persen di wilayah perkotaan dan 4,3 persen di wilayah pedesaan. Pada tabel 16 dapat diketahui bahwa dari rumah tangga penerima raskin sebanyak 15 $\mathrm{kg}$ tersebut juga masih terdapat rumah tangga yang tidak miskin yaitu di wilayah perkotaan sebanyak 2,3 persen dan di wilayah pedesaan sebanyak 1,8 persen. Sehingga rumah tangga penerima raskin yang masuk kategori rumah tangga sasaran program raskin sesuai Pedoman Umum Raskin 2015 yaitu rumah tangga sangat miskin, miskin, hampir miskin, dan rentan miskin lainnya dan menerima raskin $15 \mathrm{~kg}$ hanya sebanyak 3,1 persen (wilayah perkotaan) dan 2,6 persen (wilayah pedesaan).

Di Provinsi Jawa Tengah tahun 2015, sebagian besar rumah tangga penerima raskin menerima raskin kurang dari $15 \mathrm{~kg}$. Rumah tangga penerima raskin di wilayah perkotaan sebanyak 94,1 persen dan di wilayah pedesaan sebanyak 95,3 persen menerima raskin kurang dari $15 \mathrm{~kg}$. Sebaliknya, terdapat sebagian kecil rumah tangga yang menerima raskin lebih dari $15 \mathrm{~kg}$, hal ini dimungkinkan karena terdapat rumah tangga lain yang dialokasi raskin namun tidak bersedia mengambilnya bisa karena tidak mempunyai uang untuk menebusnya atau tidak berminat dengan raskin. Banyaknya rumah tangga penerima raskin yang menerima raskin kurang dari $15 \mathrm{~kg}$ menunjukkan bahwa distribusi raskin dilakukan dengan cara membagi rata ke rumah tangga yang bukan rumah tangga sasaran program raskin. 
Tabel 17. Persentase Rumah Tangga Penerima/Pembeli Raskin di Provinsi Jawa Tengah Menurut Jumlah Raskin yang Diterima/Dibeli, 2015

\begin{tabular}{lllll}
\hline Status Wilayah/ & Kategori & \multicolumn{4}{c}{ Jumlah Raskin yang Diterima/Dibeli } \\
& $<15 \mathrm{~kg}$ & $15 \mathrm{~kg}$ & $>15 \mathrm{~kg}$ & Jumlah \\
\hline Kemiskinan & $94,1 \%$ & $5,4 \%$ & $0,5 \%$ & $100,0 \%$ \\
\hline Perkotaan & $6,1 \%$ & $0,5 \%$ & $0,0 \%$ & $6,7 \%$ \\
-Sangat Miskin (SM) & $9,8 \%$ & $0,6 \%$ & $0,1 \%$ & $10,5 \%$ \\
-Miskin (M) & $13,1 \%$ & $0,9 \%$ & $0,0 \%$ & $14,0 \%$ \\
-Hampir Miskin (HM) & $19,7 \%$ & $1,1 \%$ & $0,1 \%$ & $20,8 \%$ \\
-Rentan Miskin Lainnya (RML) & $45,4 \%$ & $2,3 \%$ & $0,3 \%$ & $48,0 \%$ \\
-Tidak Miskin (TM) & $95,3 \%$ & $4,3 \%$ & $0,3 \%$ & $100,0 \%$ \\
Pedesaan & $6,1 \%$ & $0,4 \%$ & $0,0 \%$ & $6,4 \%$ \\
-Sangat Miskin (SM) & $8,2 \%$ & $0,6 \%$ & $0,0 \%$ & $8,8 \%$ \\
-Miskin (M) & $12,4 \%$ & $0,6 \%$ & $0,1 \%$ & $13,2 \%$ \\
-Hampir Miskin (HM) & $22,9 \%$ & $1,0 \%$ & $0,0 \%$ & $24,0 \%$ \\
-Rentan Miskin Lainnya (RML) & $45,7 \%$ & $1,8 \%$ & $0,1 \%$ & $47,6 \%$ \\
-Tidak Miskin (TM) & \multicolumn{4}{c}{. } \\
\hline
\end{tabular}

Sumber : Data Susenas 2015 Diolah

Selain menyebutkan bahwa distribusi raskin per rumah tangga sasaran program raskin adalah sebanyak $15 \mathrm{~kg} / \mathrm{RTS} /$ bulan, di dalam Pedoman Raskin 2015 juga disebutkan bahwa harga tebus raskin yang harus dibayar oleh RTS adalah sebesar Rp. 1.600,- per $\mathrm{kg}$ di titik distribusi. Sedangkan biaya transportasi dari titik distribusi ke titik bagi menjadi tanggung jawab pemerintah daerah provinsi dan kabupaten/kota. Supaya meminimalkan biaya transportasi dari titik bagi ke rumah tangga penerima raskin, maka titik bagi ditetapkan di lokasi yang strategis yang mudah dijangkau oleh rumah tangga penerima raskin.

Berdasarkan tabel 18 diketahui bahwa rumah tangga penerima raskin yang membayar harga tebus raskin sesuai Pedoman Umum
Raskin 2015 yaitu dengan harga Rp. 1.600,- per $\mathrm{kg}$ adalah sebanyak 10,1 persen (untuk wilayah perkotaan) dan 12,2 persen (untuk wilayah pedesaan). Sedangkan sebagian besar dari mereka (87,2 persen di wilayah perkotaan dan 84,9 persen di wilayah pedesaan) membayar harga tebus raskin dengan harga $>$ Rp. 1.600,per kg. Hanya sebagian kecil dari mereka yang membayar harga tebus raskin dengan harga < Rp. 1.600,- per kg. Mereka yang membayar harga tebus raskin dengan harga $>$ Rp. 1.600,- per kg dikarenakan untuk tambahan biaya transportasi dan biaya pembungkus raskin. Sedangkan untuk rumah tangga penerima raskin yang membayar biaya tebus raskin dengan harga $<\mathrm{Rp} .1 .600$,- per $\mathrm{kg}$ dikarenakan mendapat subsidi/bantuan dari orang lain atau pihak lain. 
Tabel 18. Persentase Rumah Tangga Penerima/Pembeli Raskin di Provinsi Jawa Tengah Menurut Harga Tebus Raskin yang Dibayarkan, 2015

\begin{tabular}{|c|c|c|c|c|}
\hline \multirow[b]{2}{*}{$\begin{array}{l}\text { Status Wilayah/ } \\
\text { Kemiskinan }\end{array}$} & \multicolumn{3}{|c|}{ Harga Tebus Raskin yang Dibayarkan } & \multirow[b]{2}{*}{ Jumlah } \\
\hline & $\begin{array}{ll}< & \mathrm{Rp} . \\
1.600,- & \text { per } \\
\mathrm{Kg} & \end{array}$ & $\begin{array}{l}\text { Rp. } 1.600,- \\
\text { per Kg }\end{array}$ & $\begin{array}{ll}> & \mathrm{Rp} . \\
1.600,- & \text { per } \\
\mathrm{Kg} & \end{array}$ & \\
\hline Perkotaan & $2,7 \%$ & $10,1 \%$ & $87,2 \%$ & $100,0 \%$ \\
\hline -Sangat Miskin (SM) & $0,1 \%$ & $0,7 \%$ & $5,9 \%$ & $6,7 \%$ \\
\hline -Miskin (M) & $0,3 \%$ & $0,9 \%$ & $9,3 \%$ & $10,5 \%$ \\
\hline -Hampir Miskin (HM) & $0,4 \%$ & $1,7 \%$ & $11,9 \%$ & $14,0 \%$ \\
\hline -Rentan Miskin Lainnya (RML) & $0,5 \%$ & $2,0 \%$ & $18,3 \%$ & $20,8 \%$ \\
\hline -Tidak Miskin (TM) & $1,4 \%$ & $4,8 \%$ & $41,8 \%$ & $48,0 \%$ \\
\hline Pedesaan & $2,9 \%$ & $12,2 \%$ & $84,9 \%$ & $100,0 \%$ \\
\hline -Sangat Miskin (SM) & $0,2 \%$ & $0,8 \%$ & $5,5 \%$ & $6,4 \%$ \\
\hline -Miskin (M) & $0,2 \%$ & $1,2 \%$ & $7,4 \%$ & $8,8 \%$ \\
\hline -Hampir Miskin (HM) & $0,3 \%$ & $1,7 \%$ & $11,1 \%$ & $13,2 \%$ \\
\hline -Rentan Miskin Lainnya (RML) & $0,7 \%$ & $2,7 \%$ & $20,6 \%$ & $24,0 \%$ \\
\hline -Tidak Miskin (TM) & $1,4 \%$ & $5,9 \%$ & $40,3 \%$ & $47,6 \%$ \\
\hline
\end{tabular}

Sumber : Data Susenas 2015 Diolah

\section{SIMPULAN}

Berdasarkan hasil analisis penelitian diambil kesimpula bahwa di wilayah perkotaan terdapat 10,4 persen rumah tangga yang menurut kategori kemiskinan seharusnya menerima raskin namun tidak menerima raskin dan terdapat 22,5 persen rumah tangga yang tidak miskin namun menerima raskin. Sedangkan di wilayah pedesaan terdapat 9 persen rumah tangga yang menurut kategori kemiskinan seharusnya menerima raskin namun tidak menerima raskin dan sebaliknya terdapat 34,7 persen rumah tangga yang tidak miskin namun menerima raskin, rumah tangga penerima raskin yang termasuk kategori tidak miskin di wilayah perkotaan sebesar 48 persen dan di wilayah pedesaan sebesar 47,6 persen, rumah tangga penerima raskin yang masuk kategori rumah tangga sasaran program raskin sesuai Pedoman Umum Raskin 2015 yaitu rumah tangga sangat miskin, miskin, hampir miskin, dan rentan miskin lainnya dan menerima raskin $15 \mathrm{~kg}$ hanya sebanyak 3,1 persen (wilayah perkotaan) dan 2,6 persen (wilayah pedesaan), rumah tangga penerima raskin yang membayar harga tebus raskin sesuai Pedoman Umum Raskin 2015 yaitu dengan harga Rp. 1.600,- per kg adalah hanya sebanyak 10,1 persen (untuk wilayah perkotaan) dan 12,2 persen (untuk wilayah pedesaan).

Berdasarkan uraian hasil dan keterbatasan penelitian di atas, maka dapat dikemukakan beberapa saran yaitu distribusi raskin supaya dilakukan sesuai pedoman umum raskin yaitu dengan sasaran rumah tangga penerima raskin hanya kepada rumah tangga yang sudah ditentukan berdasarkan basis data rumah tangga sasaran penerima manfaat di TNP2K dan atau rumah tangga hasil musyawarah desa/kelurahan setempat dan perlu dilakukan penelitian selanjutnya yang meneliti tentang variabelvariabel lain yang terkait distribusi raskin dan belum dapat diteliti di sini.

\section{DAFTAR PUSTAKA}

Arizal Jauhariansah. 2005. Studi Implementasi Penanggulangan Kemiskinan dalam Rangka Program Beras Keluarga Miskin (Raskin) di Kecamatan Pati Kabupaten Pati. http://www.eprints.undip.ac.id, diakses tanggal 25 Maret 2012.

Badan Pusat Statistik. 2009. Analisis Kemiskinan, Ketenagakerjaan dan 
Distribusi Pendapatan. Jakarta : Badan Pusat Statistik.

Badan Pusat Statistik. 2010. Peraturan Kepala Badan Pusat Statistik Nomor 37 Tahun 2010 Tentang Klasifikasi Perkotaan dan Pedesaan di Indonesia. Jakarta : Badan Pusat Statistik.

2012. Data dan Informasi

Kemiskinan Kabupaten/Kota 2011. Jakarta : Badan Pusat Statistik. 2013. Data dan Informasi

Kemiskinan Kabupaten/Kota 2012. Jakarta : Badan Pusat Statistik.

2013. Pedoman

Pencacahan Survei Sosial Ekonomi

Nasional Konsumsi. Jakarta : Badan Pusat Statistik.

2014. Data dan Informasi

Kemiskinan Kabupaten/Kota 2013. Jakarta : Badan Pusat Statistik.

$$
\text { 2014. Pedoman }
$$

Pencacahan Survei Sosial Ekonomi Nasional (Susenas Maret 2015). Jakarta : Badan Pusat Statistik.

2014. Pengeluaran untuk

Konsumsi Penduduk Indonesia per Provinsi September 2014. Jakarta : Badan Pusat Statistik.

2015. Data dan Informasi

Kemiskinan Kabupaten/Kota 2014.

Jakarta : Badan Pusat Statistik. 2015. Penghitungan dan Analisis Kemiskinan Makro Indonesia Tahun 2015. Jakarta : Badan Pusat Statistik.

2015. Profil Kemiskinan di Indonesia Maret 2015. Jakarta : Badan Pusat Statistik, Berita Resmi Statistik, No. 86/09/Th. XVIII, 15 September 2015.

2016. Kemiskinan. http://www.bps.go.id; diakses tanggal 19 Juli 2016.

2016. Profil Kemiskinan di

Indonesia Maret 2016. Jakarta : Badan Pusat Statistik, Berita Resmi Statistik, No. 66/07/Th. XIX, 18 Juli 2016.
BPS Provinsi Jawa Tengah. 2015. Jawa Tengah dalam Angka 2015. Semarang : BPS Provinsi Jawa Tengah.

BPS Provinsi Jawa Tengah. 2016. Jawa Tengah dalam Angka 2016. Semarang : BPS Provinsi Jawa Tengah.

BULOG. 2014. Inpres RI No. 3 Tahun 2012 Tentang Kebijakan Pengadaan Gabah/Beras dan Penyaluran Beras oleh Pemerintah : Harga Pembelian Pemerintah. http://www.bulog.co.id; diakses tanggal 13 Desember 2014.

BULOG Divre Jawa Tengah. 2013. Program Raskin Tahun 2013. Semarang : BULOG Divre Jawa Tengah.

Cahaya, Andi. 2015. Fishermen Community in the Coastal Area: A Note from Indonesian Poor Family. Economics and Finance, Volume 26, Pages 29-33.

Cheke, G. Lucy dan Nichole S. Clayton. 2015. The six blind men and the elephant: Are episodic memory tasks tests of different things or different tests of the same thing? Journal of Experimental Child Psychology, Volume 137, Pages 164-171

Dumairy. 1996. Perekonomian Indonesia. Jakarta : Erlangga.

Fernandez, Luisa and Rashiel Velarde. 2012. Who Benefits from Social Assistance in the Philippines? Evidence from the Latest National Household Surveys. The World Bank Group and Australian Goverment, Philippine Social Protection Note, March 2012, No. 4.

Imam Ghozali. 2011. Aplikasi Analisis Multivariate dengan Program IBM SPSS 19. Semarang: Badan Penerbit Univ. Diponegoro.

Itsna Mauliyawati dkk. 2004. Studi Evaluasi Kinerja Program Raskin di Kecamatan Suruh Kabupaten Semarang. Semarang : Univ. Diponegoro, "Dialogue" JIAKP, Vol. 1 No. 1, Januari 2004, hlm. 158-174.

Kementerian Komunikasi dan Informatika Direktorat Jenderal Informasi dan Komunikasi Publik. 2011. Program Penanggulangan Kemiskinan Kabinet Indonesia Bersatu II. Jakarta : Kementerian Komunikasi dan 
Informatika RI Direktorat Jenderal Informasi dan Komunikasi Publik.

Kementerian Koordinator Bidang Kesejahteraan

Rakyat Republik Indonesia. 2010.

Pedoman Umum Raskin. Jakarta :

Kementerian Koordinator Bidang

Kesejahteraan Rakyat Republik

Indonesia.

Kementerian Koordinator Bidang Kesejahteraan

Rakyat Republik Indonesia. 2011.

Pedoman Umum Raskin. Jakarta :

Kementerian Koordinator Bidang

Kesejahteraan Rakyat Republik

Indonesia.

2012. Pedoman Umum

Penyaluran Raskin. Jakarta : Kementerian

Koordinator Bidang Kesejahteraan

Rakyat Republik Indonesia. . 2013. Pedoman Umum

Subsidi Beras Bagi Masyarakat Berpendapatan Rendah 2013 (Pedum Raskin). Jakarta : Kementerian Koordinator Bidang Kesejahteraan Rakyat Republik Indonesia. 2014. Pedoman Umum

Raskin 2015. Jakarta : Kementerian

Koordinator Bidang Kesejahteraan Rakyat Republik Indonesia.

Kementerian Koordinator Bidang Kesejahteraan Rakyat dan TNP2K. 2013. Lembar Sosialisasi Program Raskin 2013. Jakarta : Kementerian Koordinator Bidang Kesejahteraan Rakyat dan TNP2K.

M. Parulian Hutagaol dan Alla Asmara. 2008. Analisis Efektivitas Kebijakan Publik Memihak Masyarakat Miskin : Studi Kasus Pelaksanaan Program Raskin di Provinsi Jawa Barat pada Tahun 2007. Jakarta : Jurnal Agro Ekonomi, Vol. 26 No. 2, Oktober 2008, hlm. 145-165.
Mariyam Musawa. 2009. Studi Implementasi Program Beras Miskin (Raskin) di Wilayah Kelurahan Gajahmungkur, Kecamatan Gajahmungkur, Kota Semarang. (Thesis Tidak Dipublikasikan, Univ. Diponegoro, 2009).

Peraturan Presiden RI. 2010. Peraturan Presiden Republik Indoneesia Nomor 15 Tahun 2010 Tentang Percepatan Penanggulangan Kemiskinan. Jakarta : Sekretariat Kabinet RI.

Rini Andrida. 2010. Analisis Efektivitas Program Raskin dan Kepuasan Rumah Tangga Penerima Manfaat di DKI Jakarta. Bogor : Program Pascasarjana Manajemen dan Bisnis Institut Pertanian Bogor.

Sulton Mawardi dkk. 2007. Efektivitas Pelaksanaan Raskin. Jakarta : Lembaga Penelitian Smeru.

Tim Nasional Percepatan dan Penanggulangan Kemiskinan (TNP2K). 2016. Data Raskin/Rastra 2016. Magelang: TNP2K.

Walker, Ruth Kennedy, et al. 2015. The impact of community social dynamics on achieving improved sanitation access for the urban poor: The case of Lusaka, Zambia. Habitat International, Volume 50, Pages 326-334 